\title{
DRY GRASSLANDS IN THE SLOVENSKÝ KRAS MTS (SLOVAKIA) AND THE AGGTELEKI-KARSZT MTS (HUNGARY) - A COMPARISON OF TWO GLASSIFICATION APPROACHES
}

\author{
Daniela DÚBRAVKOVÁ-MICHÁLKOVÁ ${ }^{1,2, *}$, Monika JANIŠOVÁ ${ }^{1,3}$, Jiří KOLBEK ${ }^{4}$, \\ Róbert ŠUVADA ${ }^{5}$, Viktor VIRÓK ${ }^{6}$ \& Mária ZALIBEROVÁ ${ }^{1}$
}

\begin{abstract}
The paper brings numerical classification of 48 new phytosociological relevés of dry grassland vegetation from the Slovenský kras Mts and the Aggteleki-karszt Mts located on the border between Slovakia and Hungary (Central Europe). We performed a comparison of two classification approaches (an unsupervised method - modified TWINSPAN, and a supervised approach - electronic expert system based on formal definitions of associations), which were applied on the same dataset. Four associations were distinguished: Campanulo divergentiformis-Festucetum pallentis Zólyomi (1936) 1966, Poo badensis-Caricetum humilis (Dostál 1933) Soó ex Michálková in Janišová et al. 2007, Alysso heterophylli-Festucetum valesiacae (Dostál 1933) Kliment in Kliment et al. 2000 and Festuco rupicolae-Caricetum humilis Klika 1939. A newly recorded stand of the rare Stipetum tirsae Meusel 1938 association is characterised. What is more, we established a neotype of the Alysso heterophylli-Festucetum valesiacae association.

Key words: Bromo pannonici-Festucion pallentis, xerophilous grassland vegetation, electronic expert system, Festucion valesiacae, modified TWINSPAN, phytosociology, supervised and unsupervised classification, syntaxonomy.

Izvleček

V članku je predstavljena numerična klasifikacija 48 novih fitocenoloških popisov vegetacije suhih travnikov iz hribovja Slovenský kras in Aggteleki-karszt na meji med Slovaško in Madžarsko (srednja Evropa). Naredili smo primerjavo dveh klasifikacijskih metod (nenadzorovano metodo - modificirani TWINSPAN, in nadzorovano metodo - elektronski ekspertni sistem, ki temelji na formalnih definicijah asociacij), ki smo ju opravili na istem podatkovnem nizu. Ločili smo štiri asociacije: Campanulo divergentiformis-Festucetum pallentis Zólyomi (1936) 1966, Poo badensis-Caricetum humilis (Dostál 1933) Soó ex Michálková in Janišová et al. 2007, Alysso heterophylli-Festucetum valesiacae (Dostál 1933) Kliment in Kliment et al. 2000 in Festuco rupicolae-Caricetum humilis Klika 1939. Označili smo tudi novo nahajališče redke asociacije Stipetum tirsae Meusel 1938. Prav tako smo definirali neotip asociacije Alysso heterophylli-Festucetum valesiacae.

Ključne besede: Bromo pannonici-Festucion pallentis, kserofilna travniška vegetacija, elektronski ekspertni sistem, Festucion valesiacae, modificirana metoda TWINSPAN, fitosociologija, nadzorovana in nenadzorovana klasifikacija, sintaksonomija.
\end{abstract}

\footnotetext{
${ }^{1}$ Institute of Botany, Slovak Academy of Sciences, Dúbravská cesta 14, 84523 Bratislava, Slovakia;

${ }^{2}$ Homeland Museum in Považská Bystrica, Ul. odborov 244/8, 01701 Považská Bystrica, Slovakia;

${ }^{3}$ Faculty of Natural Sciences, Matej Bel University, Tajovského 40, 97401 Banská Bystrica, Slovakia;

${ }^{4}$ Institute of Botany, Academy of Sciences of the Czech Republic, 25243 Průhonice, Czech Republic;

${ }^{5}$ Slovenský kras Mts NP and BR Administration, Hámosiho 188, 04951 Brzotín, Slovakia;

${ }^{6}$ Aggteleki-karszt Mts NP and BR Administration, Tengerszem oldal 1, 3758 Jósvafö, Hungary.

*Corresponding author
}

E-mail: daniela.dubravkova@savba.sk, monika.janisova@savba.sk, kolbek@ibot.cas.cz, suvada@sopsr.sk, virokvt@yahoo.com, maria.zaliberova@savba.sk 


\section{INTRODUCTION}

Vegetation of the unique dry grassland biotopes in the Slovenský kras Mts National Park and Biosphere Reserve (Slovakia) was studied by numerous top Slovak and Czech botanists in the past. The adjacent southern part of this karst area, the Aggteleki-karszt Mts National Park and Biosphere Reserve (Hungary), has been studied mainly for its flora composition. A detailed overview of botanical research in the study area was published in Michálková \& Janišová (2008). Since the area forms a homogeneous geomorphological unit, it is necessary to study its vegetation complexly. In Slovakia and Hungary, the dry grassland vegetation has been studied separately in the past, resulting in diverse syntaxonomical evaluations (Borhidi 2003, Janišová et al. 2007). To link the two national approaches, a numerical analysis of all accessible relevés from the Slovenský kras Mts and Aggteleki-karszt Mts should be performed in the future (Dúbravková et al. in prep.).

The current paper brings actual vegetation data from the study area, which has been missing until now. During three vegetation seasons we organised fieldwork excursions to collect phytosociological relevés representing the actual species composition of the dry grassland sites including the vascular plants, bryophytes and lichens. The paper reveals new vegetation data of dry grasslands of the Bromo pannonici-Festucion pallentis and the Festucion valesiacae alliances. We compared classification of the dataset based on modified TWINSPAN algorithm (Roleček et al. 2008) with classification performed using the electronic expert system for identification of associations (Janišová et al. 2007). What is more, a typification of the Alysso heterophylliFestucetum valesiacae association is performed and a new locality of Stipetum tirsae, a newly recorded association in the study area, is mentioned.

\section{MATERIAL AND METHODS}

\section{Study area}

Slovenský kras Mts and Aggteleki-karszt Mts belong to a homogeneous geomorphologic unit with identical geological structure and flora (Figure 1). It is

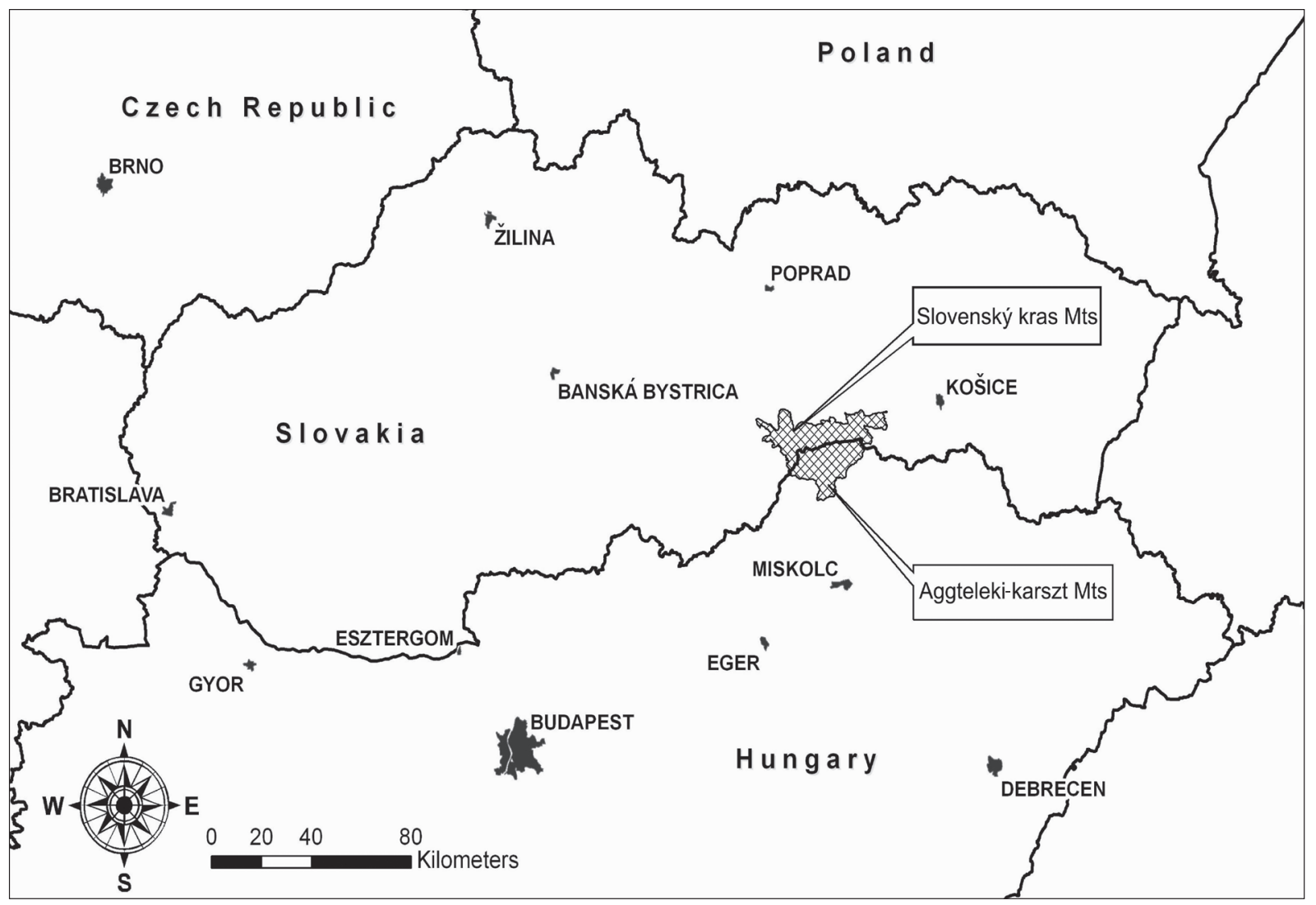

Figure 1: A map indicating location of the study area on the border between Slovakia and Hungary. Author of the map: R. Šuvada. Slika 1: Karta nahajališč na raziskovanem območju na meji med Slovaško in Madžarsko. Avtor: R. Šuvada. 
divided into two parts by a boundary line between Slovakia and Hungary, which is over $50 \mathrm{~km}$ long (Rozložník \& Karasová 1994). The territory of the Slovenský kras Mts and Aggteleki-karszt Mts is one of the greatest and very well developed karst areas in Central Europe. The today's geomorphology of the area reaches back to the history of the Neogene and Pleistocene ages. The ground water system divided the plateau area formed of limestone into a complex of plateaux with numerous surface as well as underground karst phenomena (karst rocky fields, karst hollows, caves, abysses, gorges). The major soil type is rendzina. Although forests cover the majority of the study area, the karst phenomena indicate rich presence of the xerophilous steppe vegetation in sunny slopes, rocky fields and edges of plateaux. Based on Futák (1984), the area belongs to the Pannonian phytogeographical district (Pannonicum), zone of xerophilous flora of the prae-Matra area (Matricum). However, it is in close vicinity to the Western Carpathian Mts and some montane species enrich the flora of this area.

\section{Vegetation survey and data analysis}

The phytosociological relevés used in the analyses were sampled by applying the principles of the Zürich-Montpellier school (Braun-Blanquet 1964, Westhoff \& van der Maarel 1973). They were collected during the vegetation seasons in 2005, 2006 and 2007. Longitude, latitude and altitude of the sampled sites were measured by eTrex Vista GPS set. We stored all the relevés in a TURBOWEG database (Hennekens \& Schaminée 2001). The cover values of species in all relevés were transformed into the nine-degree ordinal scale (van der Maarel 1979). Vegetation data were processed in the JUICE 6.5 software (Tichý 2002), which helped in all procedures - performing modified TWINSPAN analysis, applying the expert system and creating Table 2.

For the purpose of numerical analyses, we have merged some problematically determinable species or subspecies, which were not determined in all relevés. These taxa are: Campanula sibirica (incl. C. sibirica subsp. divergentiformis), Centaurea stoebe (incl. C. stoebe subsp. micranthos), Festuca valesiaca s. lat. (incl. $F$. valesiaca and $F$. pseudodalmatica) and Potentilla arenaria s. lat. (incl. P. arenaria and P. tommasiniana). In Table 2, in the case of Festuca valesiaca s. lat., we indicate cover values of both a merged taxon (F. valesiaca s. lat., standard font size) and a relevant ploidity stage of $F$. valesiaca s. lat. (F. valesiaca s. str. - diploid $2 \mathrm{n}=2 \mathrm{x}$ or $F$. pseudodalmatica - tetraploid $2 \mathrm{n}=4 \mathrm{x}$, smaller font size). The ploidity level of individual herbarium specimens was determined by Petr Šmarda (Masaryk University Brno, the Czech Republic) using laboratory methods. The ploidity stage of Festuca valesiaca $\mathrm{s}$. lat. is very difficult to determine directly in the field. According to our actual knowledge, the ploidity itself has no major influence on the syntaxonomical classification of the stands (Michálková 2007: 47).

The numerical classification was performed using the modified TWINSPAN algorithm, a divisive classification method sensitively respecting the internal structure of the data. As a heterogeneity measure we used the total inertia index. Three pseudospecies cut levels $(0 \%, 5 \%, 25 \%)$ were applied. The results of numerical classification are summarised in Table 2. Percentage constancy (C) is given for each species in individual clusters. In small clusters (5 or less relevés) we indicate only the presence $(\mathrm{P})$ of species in the cluster expressed as number of relevés with the species present. The diagnostic species for the clusters were selected subjectively. This selection rule was applied: constancy of diagnostic species was higher than $30 \%$ and at the same time fidelity was higher than 0.3. As a fidelity measure, we applied the phi coefficient with the Fischer's exact test at the level of significance $\mathrm{P}<0.05$ (Tichý \& Holt 2006). The size of all clusters was standardised to equal size. The dry grassland vegetation in the study area is very variable, frequently forming transitions between different communities. For this reason, and because of small number of relevés in each cluster, the diagnostic species mentioned in this paper are set as preliminary.

Besides the unsupervised classification methods such as TWINSPAN, the vegetation data can be classified using methods of supervised classification. We compared the classification of relevés in Table 2 based on modified TWINSPAN analysis with the results of classification of the same dataset, using the electronic expert system for identification of associations (Janišová et al. 2007, http://ibot.sav. sk/ES_trav_veg_Sk.doc). The expert system was designed using the Cocktail method (Bruelheide 2000, Bruelheide \& Chytrý 2000), a type of supervised classification approach. It is based on formal definitions of associations using exclusively floristic criteria (the presence of sociological species 
groups in combination with species dominance). The expert system was created for the territory of the Slovak Republic using a large stratified dataset comprising all vegetation types. In spite of this, we dare apply it also for the Aggteleki-karszt Mts in Hungary since the Slovenský kras Mts and Aggteleki-karszt Mts are a geologically and floristically integrated area. Classification procedure based on the electronic expert system was accomplished in two steps: formal definition criteria fulfillment, and similarity index calculation.

Nomenclature of vascular plants and lichens is in accordance with Marhold \& Hindák (1998), nomenclature of bryophytes with Kubinská \& Janovicová (1996). The syntaxa names and assignment of species to diagnostic species for high-level syntaxa in Table 2 follow Janišová et al. (2007). The following abbreviations were used in the paper: agg. - aggregate, cl. - cluster, C-B - Cirsio-Brachypodion pinnati, $\mathrm{E}_{2}$ - layer of shrubs, $\mathrm{E}_{1}-$ layer of herbs, $\mathrm{E}_{0}$ - layer of mosses and lichens, FPFI - frequency-positive fidelity index, incl. - inclusive (including), rel. - relevé, subsp. - subspecies, s. lat. - sensu lato (in a wide sense) and s. str. - sensu stricto (in a constricted sense). The cover values of species in Table 2 were abbreviated as follows: $2 \mathrm{a}-\mathrm{a}, 2 \mathrm{~b}-\mathrm{b}$ and $2 \mathrm{~m}-\mathrm{m}$.

\section{RESULTS}

\section{Syntaxonomy}

We identified five associations of dry grassland vegetation in the study area. Based on Janišová et al. (2007: 29) and Chytrý et al. (2007), the syntaxonomical position of these associations is as follows:

Classis: Festuco-Brometea Br.-Bl. et Tüxen ex Soó 1947

Alliancia: Bromo pannonici-Festucion pallentis Zólyomi 1966

Associatio: Campanulo divergentiformis-Festucetum pallentis Zólyomi (1936) 1966

Associatio: Poobadensis-Caricetum humilis (Dostál 1933) Soó ex Michálková in Janišová et al. 2007

Alliancia: Festucion valesiacae Klika 1931

Associatio: Alysso heterophylli-Festucetum valesiacae (Dostál 1933) Kliment in Kliment et al. 2000

Associatio: Festuco rupicolae-Caricetum humilis Klika 1939

Associatio: Stipetum tirsae Meusel 1938

\section{Classification based on modified TWINSPAN analysis}

Vegetation of the alliances Bromo pannonici-Festucion pallentis (dry grasslands of limestone and dolomite outcrops) and Festucion valesiacae (narrowleaved continental steppes) was clearly separated at the highest classification level. Along the moisture and soil-depth gradient, we separated 5 clusters at the lower hierarchical level. Clusters 1-4 represent ecologically and floristically well-defined associations. The two relevés in cluster 5 show transition in their species composition towards the CirsioBrachypodion pinnati alliance.

The open vegetation of Campanulo divergentiformis-Festucetum pallentis (Table 2, cl. 1, rel. 1-5) occurs in extremely dry rocky stands with thin soil layer. The dominant species is Festuca pallens. In some stands Carex humilis and Potentilla arenaria agg. dominate as well, which indicates a shift in succession towards the Poo badensis-Caricetum humilis association. In individual cases, some powerful competitors can take over (e. g. Anthyllis vulneraria, Bromus erectus, Stipa pulcherrima). Rare endemic taxa Astragalus vesicarius subsp. albidus and Onosma tornensis grow in this vegetation type.

The Poo badensis-Caricetum humilis association (Table 2, cl. 2, rel. 6-29; Figure 2) occurs in karst rocky fields with humus rich soil accumulated in cracks between the boulders. The community settles the deforested south-facing slopes of the karst plateaus (e. g. Plešivská planina Plateau and Dolný vrch/Alsó-hegy Plateau). Dominant species are Carex humilis, Stipa pulcherrima and Potentilla arenar$i a$ agg. In places with deeper soil, the dominants are replaced by tussock grasses (e. g. Festuca valesiaca, F. rupicola) and the vegetation composition changes into the following association.

Semi-open vegetation of the Alysso heterophylliFestucetum valesiacae association (Table 2, cl. 3, rel. 30-40; Figure 3) develops on deeper soil layers accumulated over karst limestone. The less extreme stands are located at bases of slopes where the substrate accumulation is possible. They commonly occur close to human settlements because the stands used to serve as pastures for sheep and cattle in the past.

\section{Syntaxonomical remark:}

Until now no nomenclatural type has been established for the Alysso heterophylli-Festucetum valesiacae association. Reasons for this fact are explained in Kliment et al. (2000: 169) and Michálková (2007: 40). The major problem was 


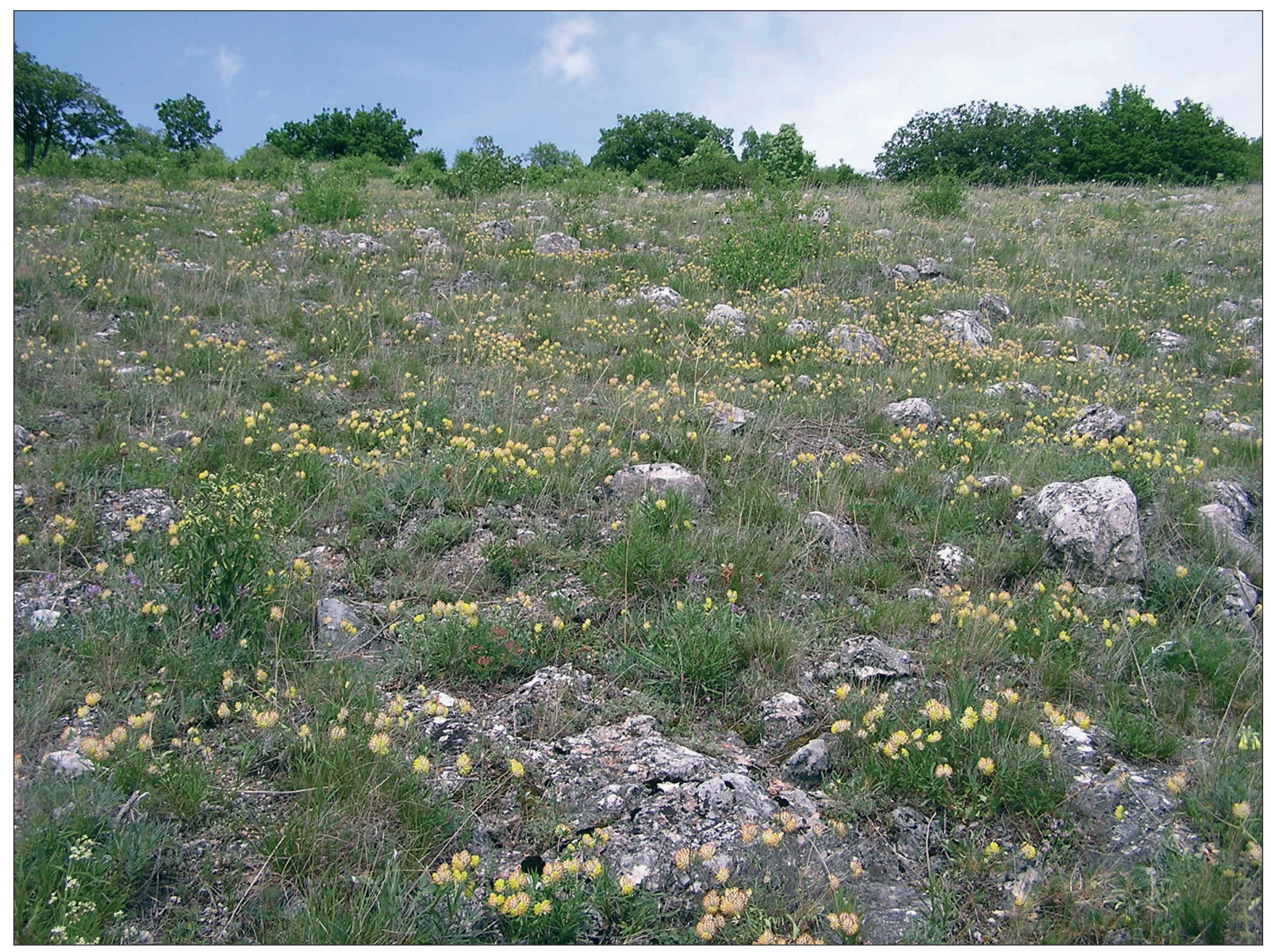

Figure 2: Poo badensis-Caricetum humilis in the Slovenský kras Mts, Turniansky hradný vrch National Nature Reserve, township of Turňa nad Bodvou, $340 \mathrm{~m}$ above sea level. The open vegetation in a stand located on a rocky karst field. Flowering taxa are Anthyllis vulneraria and Astragalus vesicarius subsp. albidus. Photo: D. Dúbravková, May 2005.

Slika 2: Asociacija Poo badensis-Caricetum humilis na hribovju Slovenský kras, nacionalni naravni park Turniansky hradný vrch, občina Turňa nad Bodvou, 340 m nad morjem. Rastišče odprte vegetacije na kamnitem kraškem polju. Cvetoči vrsti sta Anthyllis vulneraria in Astragalus vesicarius subsp. albidus. Foto: D. Dúbravková, maj 2005.

absence of a relevé containing both taxa Festuca valesiaca and Alyssum tortuosum subsp. heterophyllum, and according to the International Code of Phytosociological Nomenclature (Weber et al. 2000, Art. 16) it would be suitable to be set as a neotype. Just for this purpose we decided to trace an appropriate locality and sample a relevé. We establish relevé No. 35 in Table 2 as neotypus hoc loco of the Alysso heterophylli-Festucetum valesiacae (Dostál 1933) Kliment in Kliment et al. 2000 association. Basionym (Dostál 1933): Festucetum vallesiacae pannonicum Dostál 1933.

Compared to previous associations, Festuco rupicolae-Caricetum humilis (Table 2, cl. 4, rel. 41-44) is less extreme in water deficiency. The closed stands are located in places with colder or more humid microclimate usually near forests or shrubberies. Besides the generalists of steppe habitats, some mesophilous meadow species are also present (e. g. Arrhenatherum elatius, Filipendula vulgaris and Salvia pratensis).

The last cluster (Table 2, cl. 5, rel. 45, 46) indicates a transition between the Festucion valesiacae and the Cirsio-Brachypodion pinnati alliances. Brachypodium pinnatum was not present in the sampled stands but it dominated in their vicinity. However, relevé 45 shows close relationships to the Polygalo majorisBrachypodietum pinnati Wagner 1941 association. 


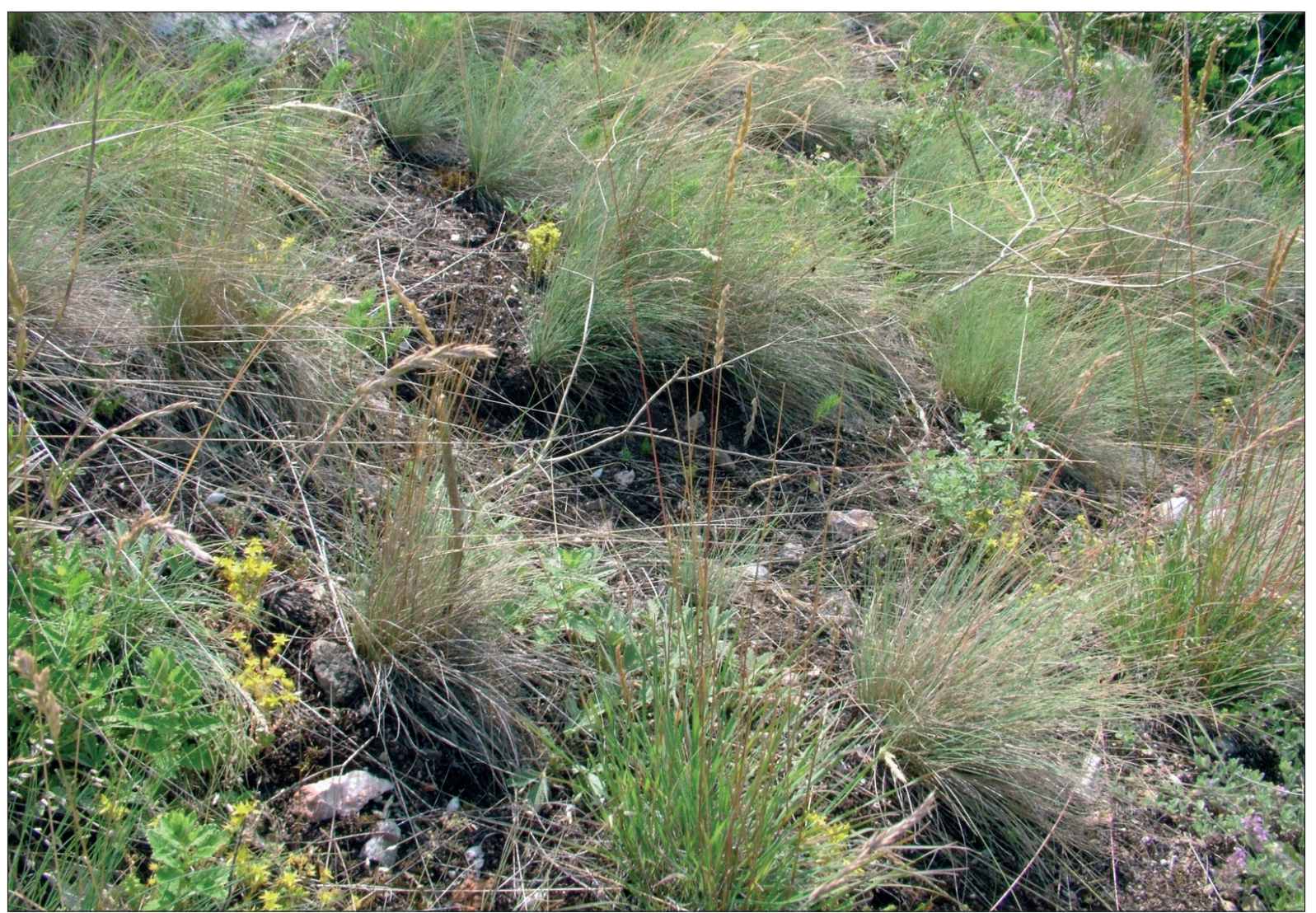

Figure 3: Alysso heterophylli-Festucetum valesiacae in the Slovenský kras Mts, Turniansky hradný vrch National Nature Reserve, township of Turňa nad Bodvou, $345 \mathrm{~m}$ above sea level. Some of the noticeable species are Festuca valesiaca, Koeleria macrantha, Sedum acre and Thymus pannonicus. Photo: R. Šuvada, June 2005.

Slika 3: Asociacija Alysso heterophylli-Festucetum valesiacae na hribovju Slovenský kras, nacionalni naravni park Turniansky hradný vrch, občina Turňa nad Bodvou, 345 m nad morjem. Najbolj opazne so vrste: Festuca valesiaca, Koeleria macrantha, Sedum acre in Thymus pannonicus. Foto: R. Šuvada, junij 2005.

\section{Classification based on the electronic expert system}

A noticeable consensus between the results of modified TWINSPAN analysis and classification of the same dataset (Table 2) using the electronic expert system for identification of syntaxa was achieved in two associations (Poo badensis-Caricetum humilis and Festuco rupicolae-Caricetum humilis, Table 1). We explain the procedure of the expert system utilization and results interpretation using the example of the Poo badensis-Caricetum humilis association. An identical technique was used for other clusters. Electronic expert system classification was accomplished in two steps: formal definition criteria fulfillment and similarity index calculation. Five of all 24 relevés from cl. 2 fulfilled the criteria of the formal definition of Poo badensis-Caricetum humilis. For the individual relevés in cl. 2, which did not meet conditions of the definition, we calculated the Frequency-Positive Fidelity Index (FPFI, Tichý 2005), which expresses the similarity of species composition of a relevé and an association to be assigned to. The highest index values do not always mean that the relevé should undoubtedly be assigned to the association at the first position. The final classification result should be carefully indicated by the author concerning several most similar associations and looking at the information regarding their environmental and chorological conditions (Janišová 2007: 27). For this reason we looked at the three highest values of similarity index FPFI. If one of the associations with first three highest numbers of FPFI was the one which was set by the modified TWINSPAN analysis (e. g. for relevés in cl. 2 it is Poo badensis-Caricetum humilis), we considered the 
relevé as correctly assigned to a proper association. The consensus of modified TWINSPAN and expert system classifications for the formal definition step, similarity measure step (FPFI) and their total is given in Table 1. Summing up, the compatibility of the two types of classification of relevés in cluster 2 was high: based on the formal definition criteria fulfillment $20.8 \%$, and based on similarity index calculation $58 \%$ of relevés were assigned to the identical association.

Based on the fulfillment of a formal definition of the Festuco rupicolae-Caricetum humilis association, 3 from the 4 relevés in cl. 3 where classified within this association.

Table 1: A comparison of classification of relevés in Table 2 based on modified TWINSPAN analysis with the results of classification using the electronic expert system for identification of associations (Janišová et al. 2007).

Tabela 1: Primerjava klasifikacij popisov iz Tabele 2 med modificirano analizo TWINSPAN in rezultatom klasifikacije z elektronskim ekspertnim sistemom za prepoznavanje asociacij (Janišová et al. 2007).

\begin{tabular}{lcccc}
\hline Association & Cluster 1 & Cluster 2 & Cluster 3 & Cluster 4 \\
\hline Number of relevés in cluster & $\begin{array}{c}\text { Campanulo } \\
\text { divergentiformis- } \\
\text { Festucetum pallentis }\end{array}$ & $\begin{array}{c}\text { Poo badensis- } \\
\text { Caricetum } \\
\text { humilis }\end{array}$ & $\begin{array}{c}\text { Alysso heterophylli- } \\
\text { Festucetum } \\
\text { valesiacae }\end{array}$ & $\begin{array}{c}\text { Festuco rupicolae- } \\
\text { Caricetum humilis }\end{array}$ \\
Rel. accomplishing a formal definition & $\mathbf{5}$ & $\mathbf{2 4}$ & $\mathbf{1 1}$ & $\mathbf{4}$ \\
Classification consensus (formal definition) & 0 & 5 & 1 & 3 \\
Rel. reaching first 3 highest values of FPFI & $0 \%$ & $20.8 \%$ & $9.1 \%$ & $75 \%$ \\
Classification consensus (FPFI) & $0 \%$ & 14 & 2 & 0 \\
Classification consensus total & $\mathbf{0 \%}$ & $58.0 \%$ & $18.2 \%$ & $0 \%$ \\
\hline
\end{tabular}

In cases of the Campanulo divergentiformis-Festucetum pallentis and the Alysso heterophylli-Festucetum valesiacae associations, the results were not so plausible.

None of the relevés, that we identified as $\mathrm{Cam}$ panulo divergentiformis-Festucetum pallentis according to the modified TWINSPAN analysis was classified within this association using the expert system. Beside the small number of relevés in cl. 1, we believe the reason is in the untypical character of the sampled sites. Degradation and successional shifts in the species composition is remarkable in the high cover values of Anthyllis vulneraria (Table 2, rel. 1-4) and Bromus erectus (rel. 5).

The formal definition of the Alysso heterophylliFestucetum valesiacae association was fulfilled only by one relevé from cl. 3. The other two relevés showed the first to the third highest level of similarity coefficient FPFI for this association (one of them was rel. 35 - the newly established neotype of the association). The total agreement in the two classification approaches is $27 \%$. Reasons for such a little correspondence might be found in a few factors. It is possible that the formal definition of the association is set quite narrowly, incorporating only a small number of relevés with very typical species composition. What is more, the variability of stands dominated by Festuca valesiaca s. lat. in Central Eu- rope is hard to trace. The vegetation comprises numerous steppe generalists and a small number of specialists, which are diagnostic for the individual communities. Therefore, besides the typical stands, a lot of relevés miss the specialists for many reasons or just by chance. The specific character of the individual communities dominated by Festuca valesiaca $\mathrm{s}$. lat. might be diminished by abandonment of the sites. The cessation of grazing leads to homogenisation of species composition of these fragile steppe communities.

\section{Stipetum tirsae Meusel 1938 - a new association in the study area}

We recorded an interesting stand dominated by Stipa tirsa in the Aggteleki-karszt Mts, locality Galyatetö (rel. 1). A similar site occurs also in Szőlő-hegy Mt. (Figure 4). Stipa tirsa is a species of continental distribution, which occurs in Central Europe in relic localities indicating the former Pleistocene steppes (Chytrý et al. 2007: 422).

This vegetation syntaxonomically belongs to the Stipetum tirsae association. Compared to the diagnostic species listed in Chytrý et al. (2007: 421), four species are in common: Festuca rupicola, Fragaria viridis, Stipa tirsa and Thymus pannonicus. 


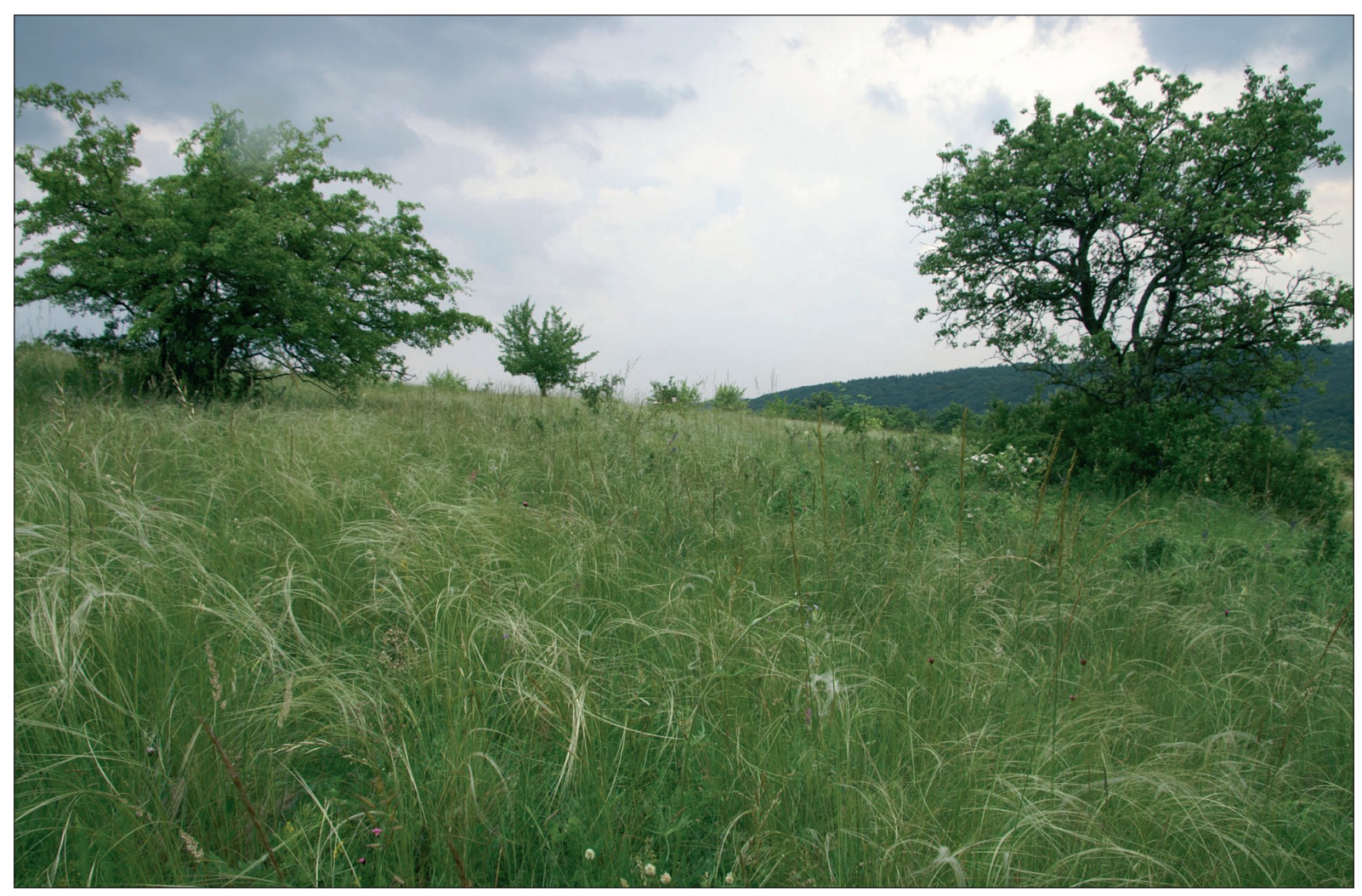

Figure 4: Stipetum tirsae in the Aggteleki-karszt Mts, Szőlő-hegy Mt., township of Jósvafő, $324 \mathrm{~m}$ above sea level. Photo: V. Virók.

Slika 4: Asociacija Stipetum tirsae na hribovju Aggteleki-karszt, hribovje Szőlő-hegy, občina Jósvafo, $324 \mathrm{~m}$ nad morjem. Foto: V. Virók.

In place of the diagnostic moss Weissia brachycarpa, $W$. controversa occurs in our stand. The numerical analysis showed a close relationship of this relevé to Festuco rupicolae-Caricetum humilis. Both associations are the least xerophilous associations within the Festucion valesiace alliance. The slightly mesic character of the stand is fully reflected in the species composition (rel. 1). This also may be caused by shrubs, which partly shade the locality.
The stands of Stipetum tirsae are usually speciespoor (Meusel 1938, Chytrý et al. 2007). Relevé 1 includes as many as 42 species, however cover value of 14 species does not exceed $1 \%$ (r). These species were leaf rosettes and isolated individuals, which penetrated into the stand from species-rich surrounding vegetation types (fringe vegetation and rocky dry grasslands).

\section{Relevé 1}

HU, Aggteleki-karszt Mts, Aggtelek, Galya-tetö, upper part of a karst rocky field above the village, a grassland surrounded by shrubs, $48^{\circ} 28^{\prime} 19^{\prime \prime} \mathrm{N}, 20^{\circ} 30^{\prime} 43^{\prime \prime} \mathrm{E}, 20 \mathrm{~m}^{2}, 396 \mathrm{~m}$ a. s. l., W $\left(260^{\circ}\right), 30^{\circ}, \mathrm{E}_{\mathrm{t}} 100 \%, \mathrm{E}_{1} 100 \%, \mathrm{E}_{0} 2 \%$, V. Virók, D. Dúbravková \& E. Illyés, 39/06, 29. 5. 2006.

$\mathbf{E}_{1}$ : Stipa tirsa 4, Festuca rupicola 2b, Achillea pannonica 2a, Fragaria viridis 2a, Arrhenatherum elatius 1, Salvia pratensis 1 , Agrimonia eupatoria +, Allium flavum +, Brachypodium sylvaticum +, Dorycnium pentaphyllum agg. +, Eryngium campestre + , Tithymalus cyparissias + , Koeleria macrantha + , Poa angustifolia + , Potentilla arenaria + , Sedum sexangulare + , Teucrium chamaedrys +, T. montanum +, Thymus pannonicus +, Vicia angustifolia + , V. hirsuta + , Ligustrum vulgare juv. + , Prunus spinosa juv. +, Rosa canina agg. juv. +, Carduus nutans r, Daucus carota r, Echinops sphaerocephalus r, Filipendula vulgaris r, Geranium pusillum r, Lepidium campestre r, Myosotis arvensis r, Picris hieracioides r, Pyrus pyraster juv. r, Ranunculus bulbosus $\mathrm{r}$, Stachys germanica $\mathrm{r}$, Vincetoxicum hirundinaria $\mathrm{r}$, Viola hirta $\mathrm{r}$.

$\mathbf{E}_{0}$ : Brachythecium glareosum + , Schistidium apocarpum + , Thuidium abietinum + , Weissia controversa + . 


\section{DISCUSSION AND CONCLUSIONS}

The comparison of classification of the same dataset using an unsupervised method (TWINSPAN) and a supervised approach (expert system) brought some interesting points to discuss.

Both of the classification approaches have advantages and disadvantages. The divisive (TWINSPAN) and agglomerative classification methods (cluster analyses) seek to find major gradients in data variability and the algorithm used creates clusters as homogeneous as possible, according to the internal information in the analysed data set. The variability of species composition in plant communities is usually continuous (Chytrý 2007: 20). Therefore the "sharp edges" between clusters might sometimes be artificially defined. For the purpose of clusters' interpretation, the unifying features of clusters as complex units are emphasised. There is a risk that a cluster might include some rather different relevés just because they are most similar to this cluster concerning the whole analysed dataset. This might distort the results of classification.

On the other hand, the expert system applies an individual approach to relevés, which leads to a less generalised interpretation of classification. The supervised classification uses external predefined criteria of what the individual vegetation units should look like. These criteria are independent from the classified dataset. This means that the actually analysed data do not serve as a dataset for calibration of the classification. The expert system was calibrated by a dataset, which served for its creation - a stratified dataset including all vegetation types of the territory for which it was created (it was Slovakia in our case). Although the accuracy of correct classification of relevés depends on numerous factors, it still remains a great tool for relevés classification.

An important advantage of the expert system usage lies in the identification of transitional stands. For example, rel. 3 and 4 in Table 2 were classified as Poo badensis-Caricetum humilis; rel. 8, 19, 39, 40, 46 in Table 2 and rel. 1 mentioned in the text (Stipetum tirsae) were identified as Festuco rupicolaeCaricetum humilis. Although these results cannot be implicitly accepted by the modified TWINSPAN analysis and our field observations, it is evident that the species composition of these particular relevés is shifted towards the mentioned associations.

Concluding the results, we find combined usage of both unsupervised method (divisive or agglomerative classification) and supervised method (expert system) to be a very informative and fa- vourable tool for the vegetation data classification. However, the expert knowledge and experience of a researcher performing the classification remain one of the key factors in correct interpretation of any classification approach.

\section{ACKNOWLEDGEMENTS}

We are obliged to the following botanists for determination or revision of individual plant groups: Anna Kubinská (Institute of Botany SAS Bratislava, Slovakia) and Anna Petrášová (Matej Bel University Banská Bystrica, Slovakia) determined the specimens of bryophytes; Ivan Pišút and Alica Dingová (Institute of Botany SAS Bratislava, Slovakia) determined the lichens; specimens of the genus Achillea were revised by Jiří Danihelka (Masaryk University Brno, the Czech Republic), the genus Festuca by Petr Šmarda (Masaryk University Brno, the Czech Republic), the genus Orobanche by Jiř́ Zázvorka (Institute of Botany AS CR Průhonice, the Czech Republic) and the genus Thymus by Pavol Mártonfi (P. J. Šafárik University Košice, Slovakia). We are also grateful to Ján Kliment (Botanical Garden of the Comenius University Bratislava, Slovakia) for his comments on the typification procedure. We are deeply indebted to Eszter Illyés (Institute of Ecology and Botany HAS Vácrátót, Hungary) for intense cooperation during the fieldwork and to Michael Harris (University of Liverpool, Great Britain) who performed proofreading of the manuscript. This research study was funded by Slovak research projects VEGA 2/5084/25 and APVT-51-015804. Participation of the third author was possible due to the Czech research project AVOZ 60050516.

\section{REFERENCES}

Borhidi, A. (ed.) 2003: Magyarország novénytársulásai. Akadémiai kiadó, Budapest, 610 pp.

Braun-Blanquet, J. 1964: Pflanzensoziologie. Grundzüge der Vegetationskunde. Ed. 3. Springer Verlag, Wien, 865 pp.

Bruelheide, H. 2000: A new measure of fidelity and its application to defining species groups. Journal of Vegetation Science 11: 167-178.

Bruelheide, H. \& Chytrý, M. 2000: Towards unification of national vegetation classifications: A comparison of two methods for analysis of large data sets. Journal of Vegetation Science 11: 295-306. 
Chytrý, M. 2007: Vymezení vegetačních jednotek a ich interpretace. In: Chytrý, M. (ed.): Vegetace České republiky. 1. Travinná a keříčková vegetace. Academia, Praha, pp. 19-34.

Chytrý, M., Hoffmann, A. \& Novák, J. 2007: Suché trávníky (Festuco-Brometea). In: Chytrý, M. (ed.): Vegetace České republiky. 1. Travinná a keříčková vegetace. Academia, Praha, pp. 371-497.

Dostál, J. 1933: Geobotanický přehled vegetace Slovenského krasu. Věstník Královské české společnosti nauk, Tř. 2., Praha, 4: 1-44.

Futák, J. 1984: Fytogeografické členenie Slovenska. In: Bertová, L. (ed.): Flóra Slovenska IV/1. Veda, Bratislava, pp. 418-419.

Hennekens, S. M. \& Schaminée, J. H. J. 2001: TURBOVEG, a comprehensive data base management system for vegetation data. Journal of Vegetation Science 12: 589-591.

Janišová, M. 2007: Introduction and methods. In: Janišová, M., Hájková, P., Hegedüšová, K., Hrivnák, R., Kliment, J., Michálková, D., Ružičková, H., Řezníčková, M., Tichý, L., Škodová, I., Uhliarová, E., Ujházy, K \& Zaliberová, M. 2007: Travinnobylinná vegetácia Slovenska - elektronický expertný systém na identifikáciu syntaxónov. (Grassland vegetation of Slovakia - electronic expert system for syntaxa identification). Botanický ústav SAV, Bratislava, pp. 22-29.

Janišová, M., Hájková, P., Hegedüšová, K., Hrivnák, R., Kliment, J., Michálková, D., Ružičková, H., Řezníčková, M., Tichý, L., Škodová, I., Uhliarová, E., Ujházy, K \& Zaliberová, M. 2007: Travinnobylinná vegetácia Slovenska - elektronický expertný systém na identifikáciu syntaxónov. (Grassland vegetation of Slovakia - electronic expert system for syntaxa identification). Botanický ústav SAV, Bratislava, 265 pp.

Kliment, J., Hrivnák, R., Jarolímek, I. \& Valachovič, M. 2000: Nelesné spoločenstvá Drienčanského krasu. In: Kliment, J. (ed.): Príroda Drienčanského krasu. ŠOP SR, Banská Bystrica, pp. 155-190.

Kubinská, A. \& Janovicová, K. 1996: A Second Checklist and Bibliography of Slovak Bryophytes. Biologia 51/Suppl. 3: 81-146.

Marhold, K. \& Hindák, F. (eds) 1998: Zoznam nižších a vyšších rastlín Slovenska. Veda, Bratislava, 688 pp.

Meusel, H. 1938: Über das Vorkommen des Schmalblättrigen Federgrass, Stipa stenophylla Čern., im nördlichen Harzvorland. Hercynia 1: 285-308.

Michálková, D. 2007: Festucion valesiacae Klika 1931. In: Janišová, M., Hájková, P., Hegedüšová, K., Hrivnák, R., Kliment, J., Michálková, D., Ružič- ková, H., Řezníčková, M., Tichý, L., Škodová, I., Uhliarová, E., Ujházy, K \& Zaliberová, M.: Travinnobylinná vegetácia Slovenska - elektronický expertný systém na identifikáciu syntaxónov. (Grassland vegetation of Slovakia - electronic expert system for syntaxa identification). Botanický ústav SAV, Bratislava, pp. 33-49.

Michálková, D. \& Janišová, M. 2008: Xerotermná vegetácia Slovenského a Aggteleckého krasu prehlad najnovších výsledkov výskumu. (Dry grassland vegetation of the Slovak karst (Slovakia) and Aggtelek karst (Hungary) - overwiev of new results). Proceedings of the $7^{\text {th }}$ national conference for Biosphere Reserves in Slovakia, Rožňava, 20.-21.11. 2007, in press.

Roleček, J., Tichý, L., Zelený, D. \& Chytrý, M. 2008: Modified TWINSPAN classification with the hierarchy respecting cluster heterogeneity. Journal of Vegetation Science, in press.

Rozložník, M. \& Karasová, E. (eds) 1994: CHKOBR Slovenský kras. Osveta, Martin, 480 p.

Tichý, L. \& Holt, J. 2006: JUICE program for management, analysis and classification of ecological data. First version of the program manual. Masarykova univerzita, Brno, URL [http:// www.sci.muni.cz/botany/juice/]

Tichý, L. 2002: JUICE, software for vegetation classification. Journal of Vegetation Science 13: 451453.

Tichý, L. 2005: New similarity indices for the assignment of relevés to the vegetation units of an existing phytosociological classification. Plant Ecology 179: 67-72. (DOI: 10.1007/s11258-0045798-8).

van der Maarel, E. 1979: Transformation of coverabundance values in phytosociology and its effect on community similarity. Vegetatio 39: 97-114.

Weber, H. E., Moravec, J. \& Theurillat, J.-P. 2000: International Code of Phytosociological Nomenclature. Ed. 3. Journal of Vegetation Science 11: 739-768.

Westhoff, V. \& van der Maarel, E. 1973: The BraunBlanquet approach. In: Whittaker, R. H. (ed.): Ordination and Classification of Communities. Dr. W. Junk Publishers, The Hague, pp. 617727. 


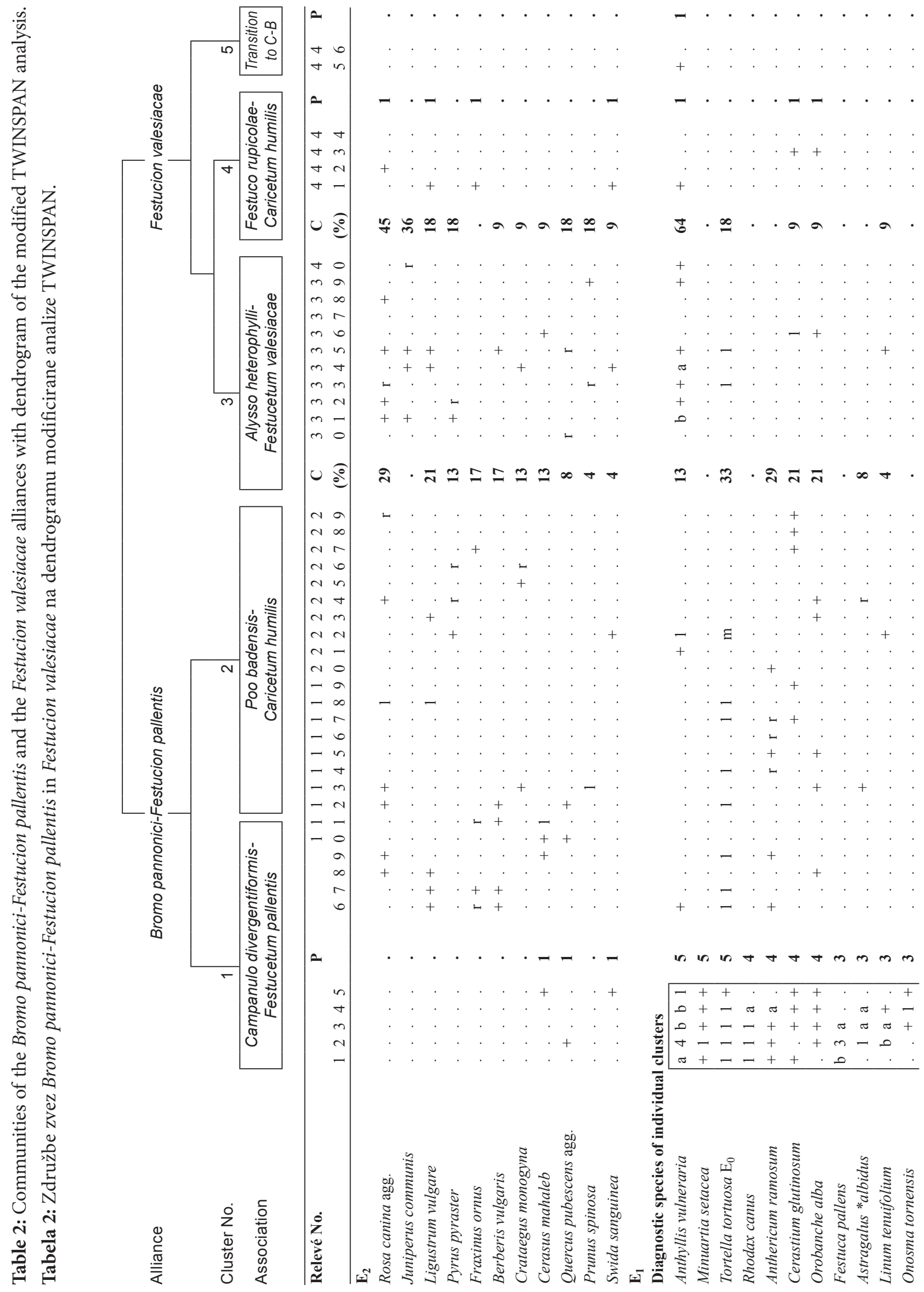




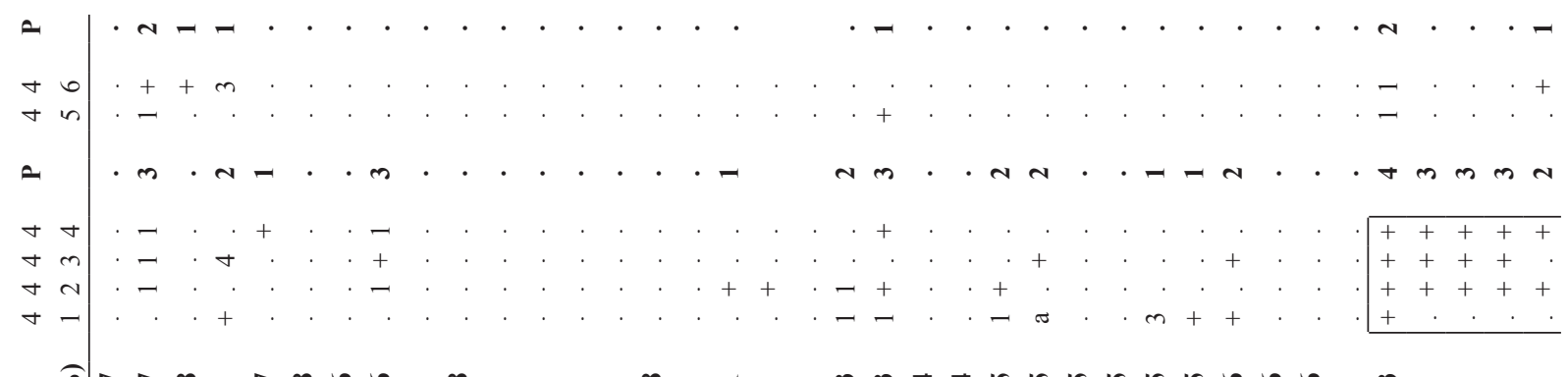

ט

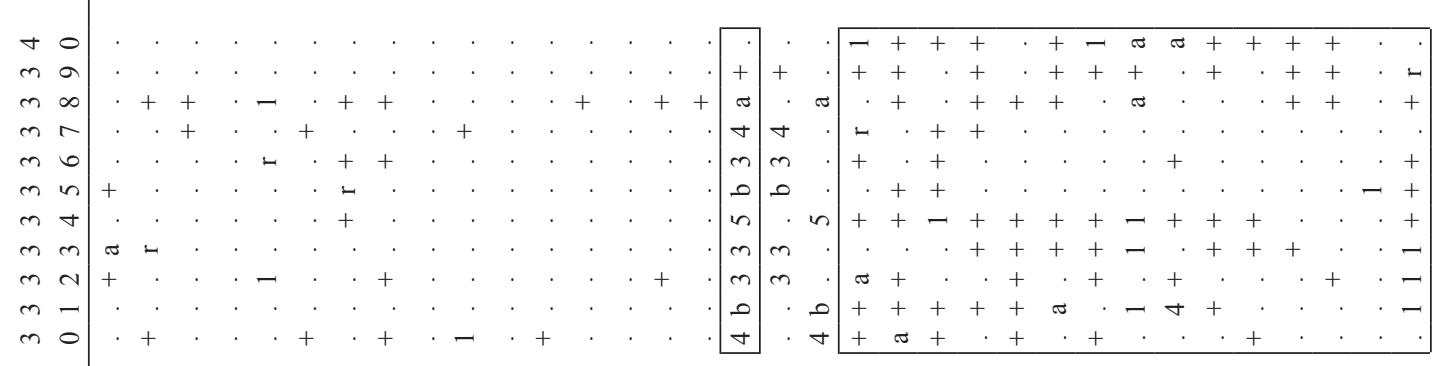

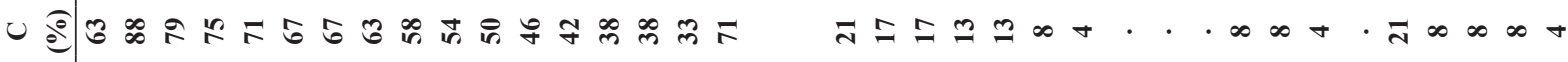

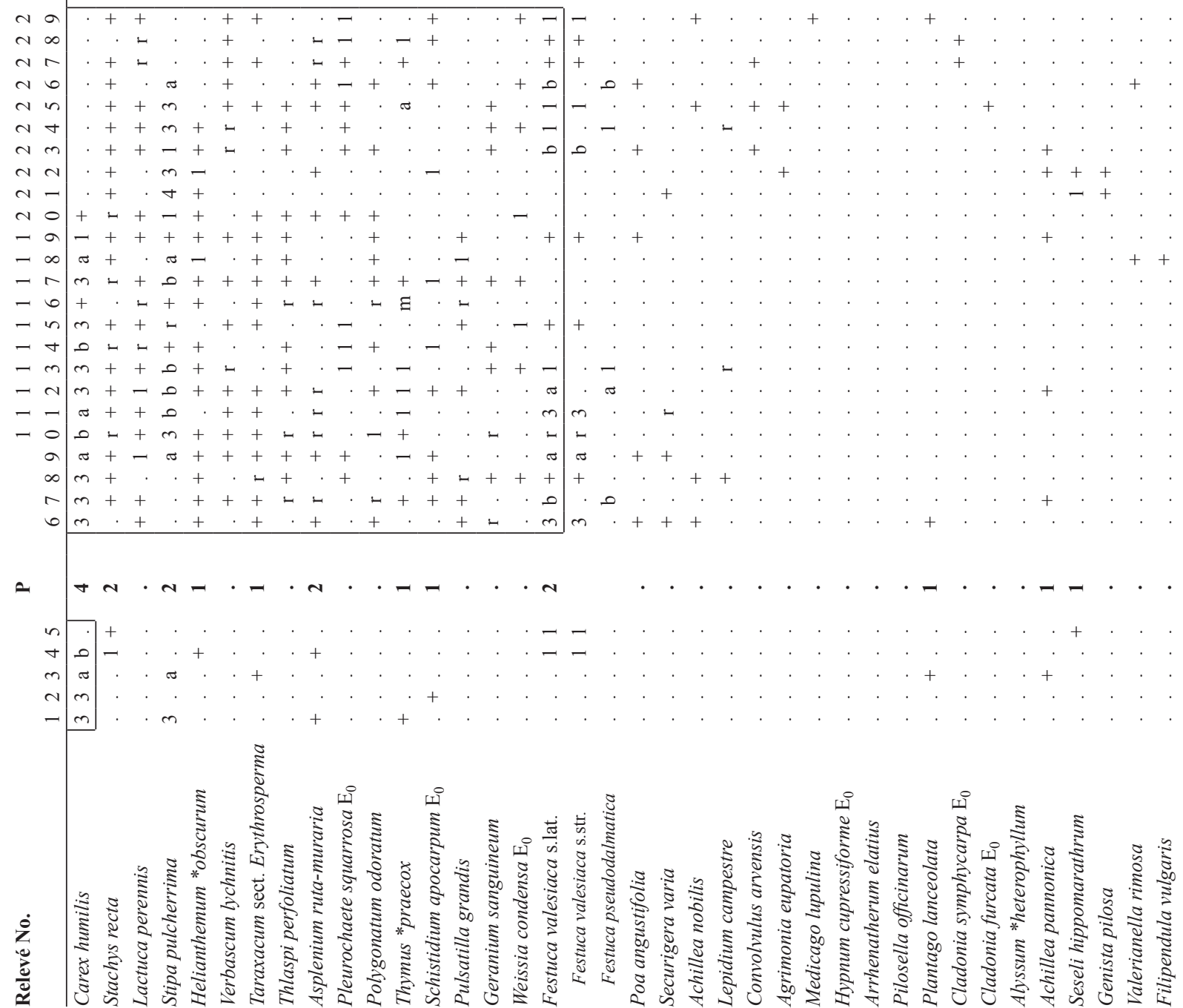



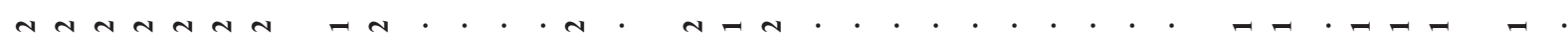

\begin{tabular}{lllllll|}
0 & 0 & + & + & + & + & + \\
$\bullet$ & - & - & + & + & + & +
\end{tabular}

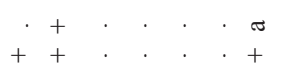

$+\quad+$
$+\quad+$

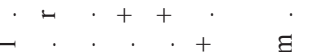

\begin{tabular}{l}
$\nabla$ \\
\hline$n$ \\
$n$ \\
+
\end{tabular}

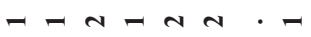

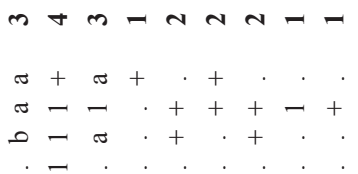

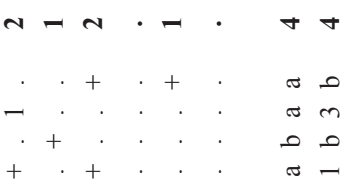

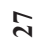

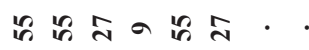

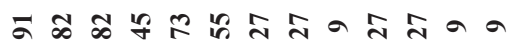

미요요
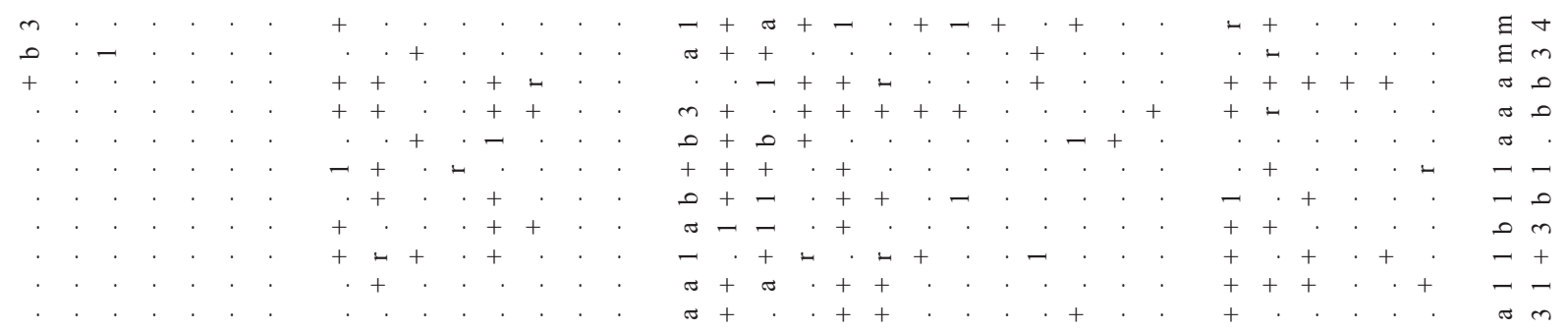

$=m+\cdot \infty$

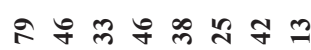

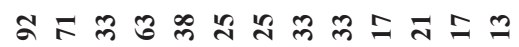

iิ

ฉ゚

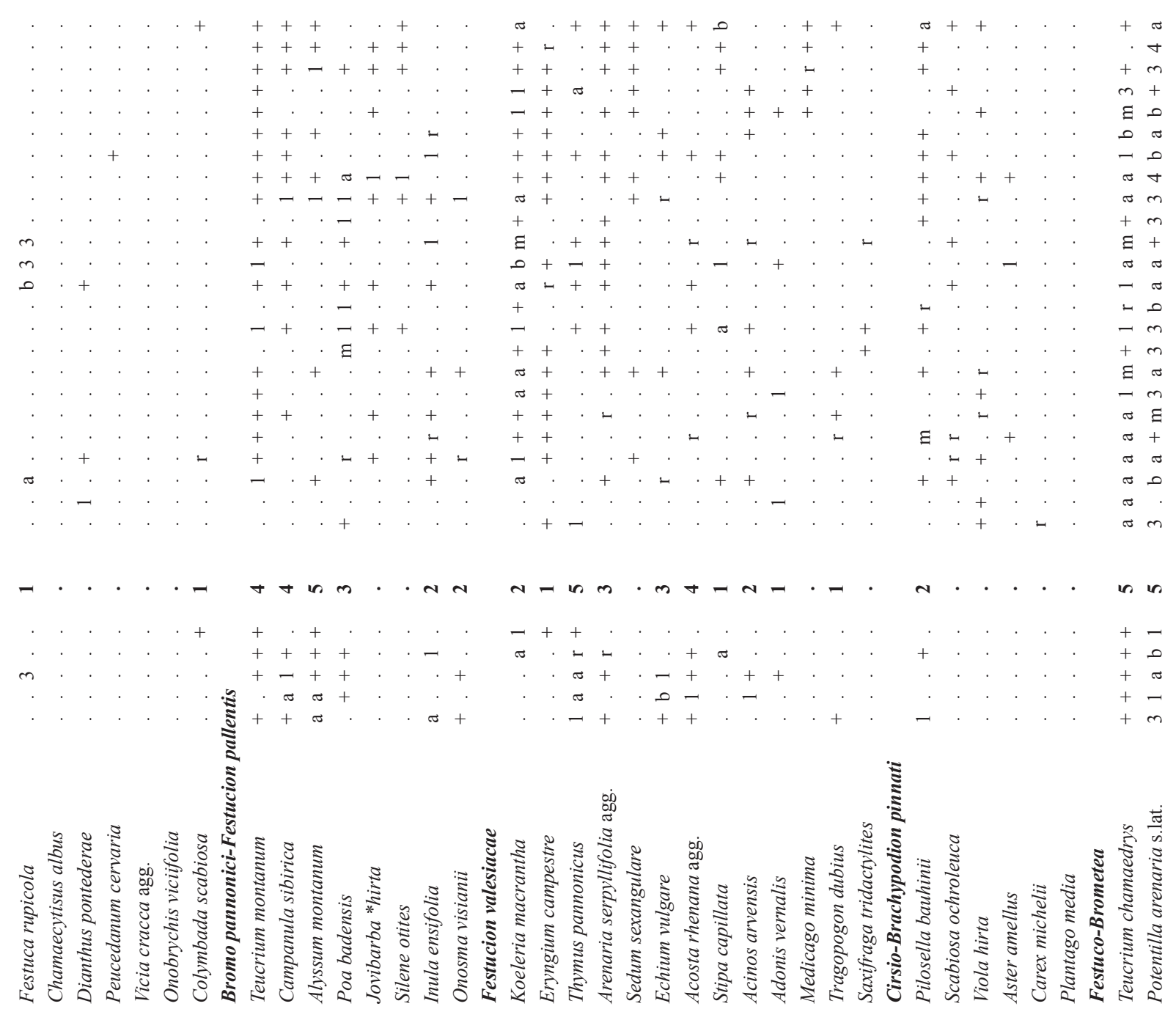




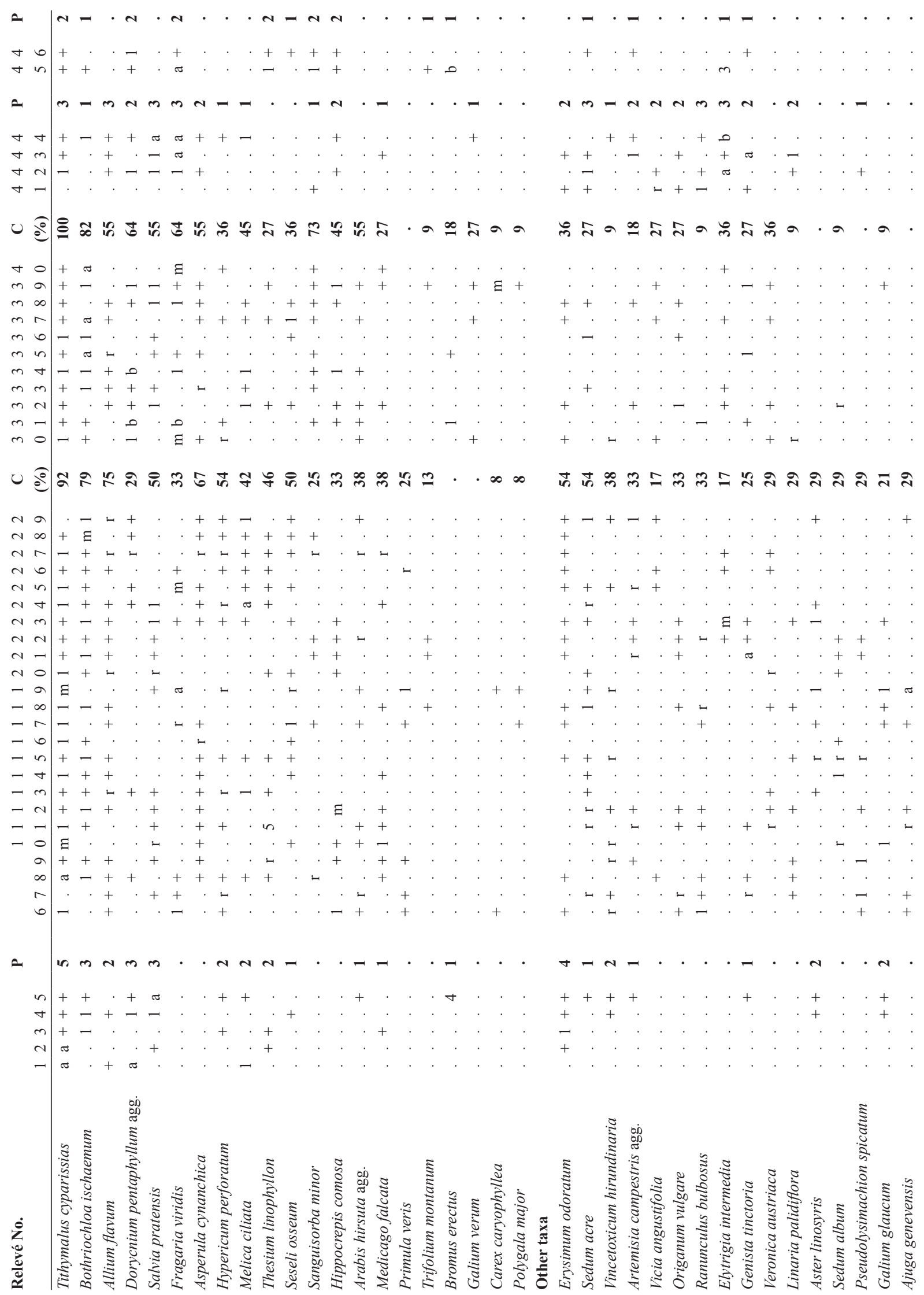


-

$\stackrel{\infty}{\sim} \cdot a \stackrel{\infty}{\sim}$

- $\underset{1}{\sim}$

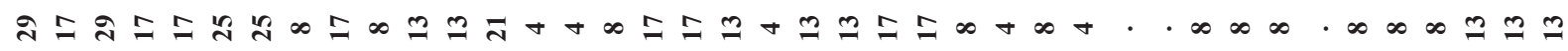
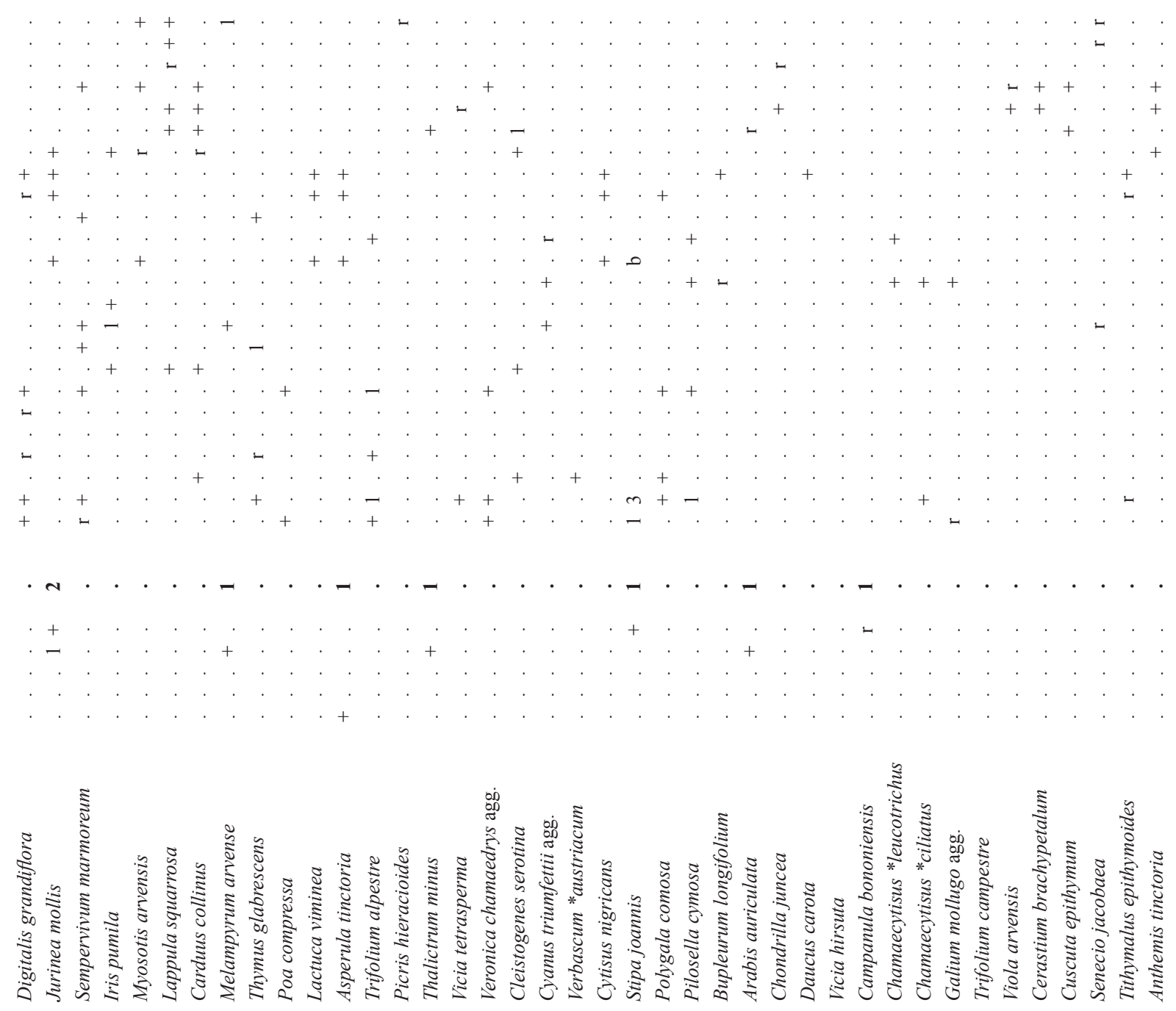
Hacquetia 7/2 • 2008, 123-140
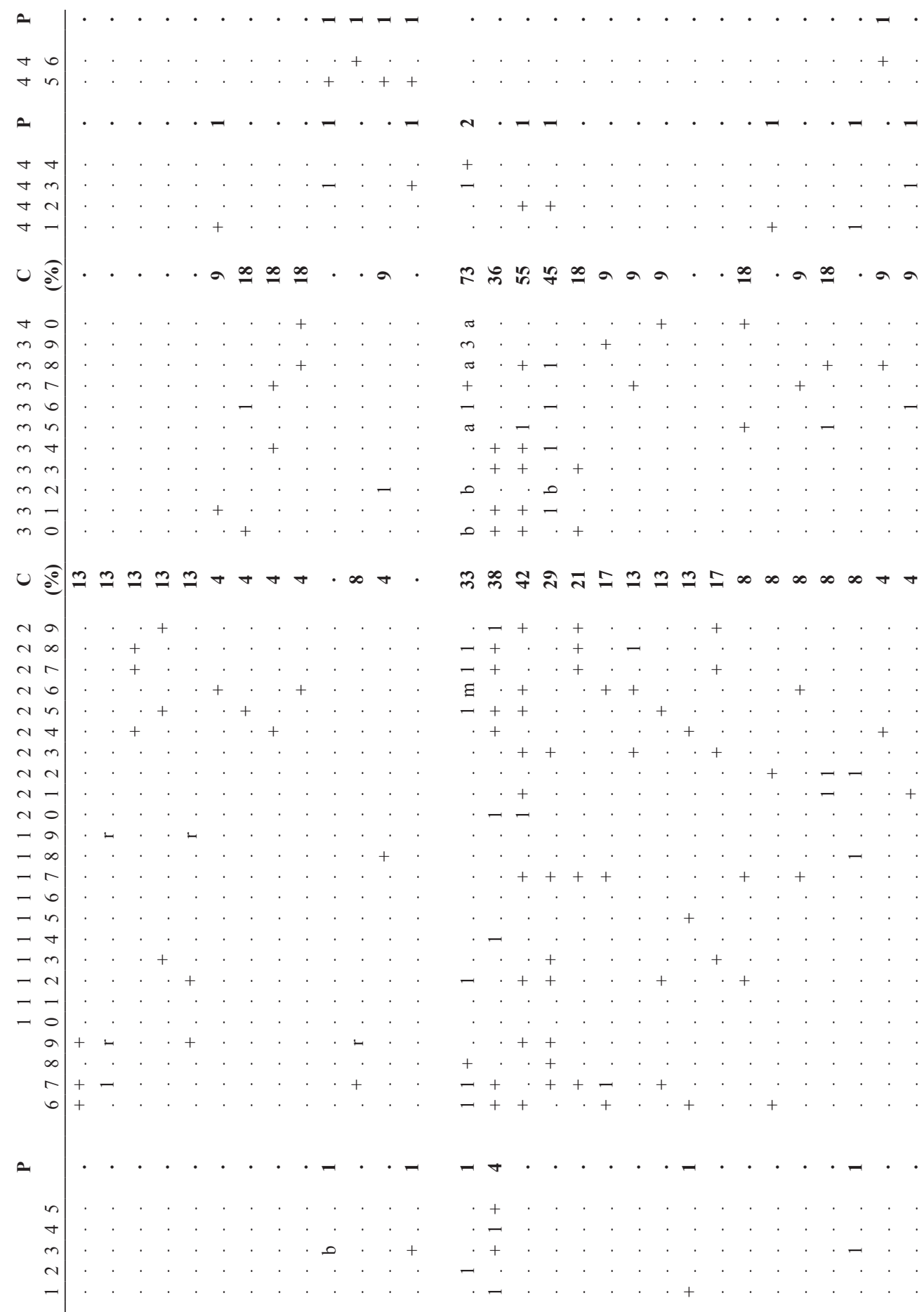

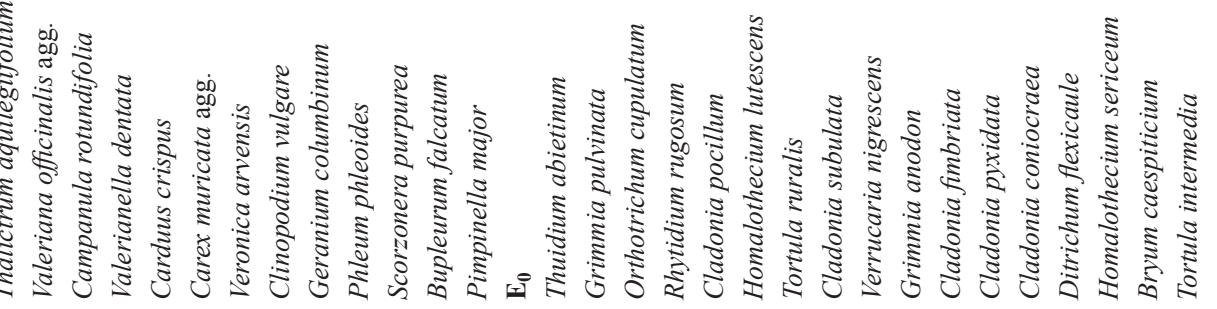

138 


\section{Species present in one or two relevés:}

$\mathbf{E}_{2}$ : Acer campestre 41: 1; Carpinus betulus 38: r, 41: +; Cornus mas 5: +, 34: +; Rhamnus cathartica 7: +, 38: +; Rosa gallica 23: $r$; Spiraea media 9: r; Viburnum lantana 5: +, 38: +;

$\mathbf{E}_{1}$ : Aconitum anthora 7: +; Allium senescens subsp. montanum 3: 1; Alyssum alyssoides 15: +, 30: +; A. montanum subsp. brymii 9: +, Arabidopsis thaliana 15: +; Asplenium trichomanes 6: r; Avenula praeusta 46: +; Brachypodium pinnatum 6: r, 12: r; Bupleurum affine 24: r; Camelina microcarpa 18: r; Campanula trachelium 45: +; Cerastium holosteoides 31: +; C. semidecandrum 15: +; Cerinthe minor 41: +; Clematis vitalba 46: r; Crupina vulgaris 24: +, 29: +; Cytisus procumbens 17: +, 19: +; Eremogone micradenia 9: +, 17: +; Erysimum diffusum agg. 24: r, 35: +; Falcaria vulgaris 23: 1, 39: +; Fallopia convolvulus 7: r, 23: +; Festuca csikhegyensis Simonk. 9: +, F. pratensis agg. 31: 1, 34: +; F. pseudodalmatica x F. pallens 21: +; F. rubra agg. 34: +, 41: 1; Fumaria schleicheri 10: r; Galium boreale 45: +; G. pumilum 29: +; Geranium dissectum 44: +; Geum urbanum 34: +; Globularia punctata 8: +, 45: 2a; Hieracium bauhinii 35: +; Holosteum umbellatum 25: +, 36: +; Hylotelephium maximum 15: +; Inula conyza 11: r; I. hirta 9: +; Isatis praecox 6: r, 9: +; Knautia arvensis 45: +; Lamium amplexicaule 25: +; Lathyrus heterophyllus 18: +, 45: +; L. pannonicus 44: +; Leopoldia tenuiflora 13: 1, 39: +; Libanotis pyrenaica 46: 1; Linaria vulgaris 25: +; Linum catharticum 31: 1, 41: +; Lithospermum arvense 36: r, 41: +; L. officinale 11: +; Lotus corniculatus agg. 39: +; Melilotus officinalis 25: 1; Mentha arvensis 31: +; Nonea pulla 42: +, 45: +; Odontites vulgaris 27: +, 30: +; Orchis tridentata 10: +, 14: r; Petrorhagia prolifera 25: +, 29: +; Pimpinella saxifraga agg. 1: +, 30: +; Piptatherum virescens 22: r; Potentilla argentea agg. 41: +; P. heptaphylla 7: 1; P. recta 36: +; Prunella grandiflora 21: r; Ranunculus illyricus 3: +; Reseda lutea 2: +; Salvia verticillata 39: r, 46: +; Saxifraga paniculata 4: +; Scorzonera austriaca 8: +; Sesleria heufleriana 12: +; Silene bupleuroides 32: +; S. donetzica subsp. sillingeri 36: r; S. latifolia subsp. alba 41: +; S. nutans 31: 1; Stachys germanica 31: +; Stellaria graminea 41: +; Tanacetum corymbosum 38: +; Taraxacum sect. Ruderalia 26: r, 41: r; Tragopogon orientalis 41: r; Trifolium arvense 40: +; T. pratense 41: +; T. repens 31: 1; T. sarosiense 12: +; Trinia glauca 17: +, 19: +; Thalictrum foetidum 15: r; Tephroseris integrifolia 37: r; Thymus x subhirsutus 8: +, 24: 1; Valerianella locusta 36: +; Verbascum nigrum 45: +; V. phoeniceum 7: +; Veronica prostrata 35: r; Vinca herbacea 8: +, 13: +; Waldsteinia geoides 41: 1;

$\mathrm{E}_{0}$ : Aspicilia contorta 14: +, 17: +; Barbula unguiculata 8: +, 37: +; Brachythecium glareosum 37: +; Bryum argenteum 20: 1, 21: +; B. capillare 28: +; Cetraria islandica 35: 1; Cladonia chlorophaea 41: +; C. polycarpoides 32: +, 42: +; C. ramulosa 35: +; C. subfurcata 30: +; Collema fuscovirens 27: +; C. cristatum 6: +, 25: +; Didymodon acutus 23: +; D. cordatus 13: +; Diploschistes muscorum 38: +; Ditrichum heteromallum 3: +; Encalypta vulgaris 1: 1; Fissidens dubius 17: 1; Lecanora dispersa 7: +; L. muralis 25: +, 27: +; Lobothallia radiosa 33: +; Porella platyphylla 17: +; Rinodina bischoffi 12: +; Toninia athallina 9: +; T. tumidula 6: +; T. sedifolia 13: +; Tortella inclinata 43: 1; Squamarina sp. 1: +, 21 : +; Staurothele rufa 13: +; Verrucaria muralis 12: +, 27: +; Weissia longifolia 40: 1.

\section{Locations of relevés}

Relevé number, country code (HU - Hungary, SK - Slovakia), detailed description of the locality, latitude, longitude, relevé area, altitude, aspect in letters and degrees $\left(\mathrm{E} 90^{\circ}, \mathrm{S} 180^{\circ}\right.$, W $\left.270^{\circ}, \mathrm{N} 360^{\circ}\right)$, slope, cover total $\left(\mathrm{E}_{\mathrm{t}}\right)$, cover of shrub layer $\left(\mathrm{E}_{2}\right)$, cover of herb layer $\left(\mathrm{E}_{1}\right)$, cover of mosses and lichens $\left(\mathrm{E}_{0}\right)$, cover of bare rock $\left(\mathrm{E}_{\mathrm{r}}\right)$, relevé author(s), field number, date (day/month/year).

1. SK, Slovenský kras Mts, Hrhov, Okrúhle Mt., 48³6'36"N, $20^{\circ} 46^{\prime} 57^{\prime \prime} \mathrm{E}, 25 \mathrm{~m}^{2}, 376 \mathrm{~m}, \mathrm{~S}\left(180^{\circ}\right), 50^{\circ}, \mathrm{E}_{\mathrm{t}} 80 \%, \mathrm{E}_{2} 10 \%, \mathrm{E}_{1} 70 \%, \mathrm{E}_{0}$ $15 \%, \mathrm{E}_{\mathrm{r}} 30 \%$, D. Dúbravková \& M. Zaliberová, 27/05, 3. 6. 2005.

2. SK, Slovenský kras Mts, Dvorníky, Zemné hradisko Nature Reserve, the stand is located in a patch with dominance of Anthylis vulneraria, $48^{\circ} 36^{\prime} 16^{\prime \prime} \mathrm{N}, 20^{\circ} 48^{\prime} 51^{\prime \prime} \mathrm{E}, 25 \mathrm{~m}^{2}, 290 \mathrm{~m}, \mathrm{E}\left(90^{\circ}\right)$, $10^{\circ}, \mathrm{E}_{\mathrm{t}} 90 \%,-, \mathrm{E}_{1} 90 \%, \mathrm{E}_{0} 10 \%, \mathrm{E}_{\mathrm{r}} 10 \%$, D. Dúbravková \& M. Zaliberová, 25/05, 3.6. 2005.

3. SK, Slovenský kras Mts, Dvorníky, Zemné hradisko Nature Reserve, the stand is located in a small patch with dominance of Anthylis vulneraria, $48^{\circ} 36^{\prime} 18^{\prime \prime} \mathrm{N}, 20^{\circ} 48^{\prime} 56^{\prime \prime} \mathrm{E}, 25 \mathrm{~m}^{2}, 280 \mathrm{~m}, \mathrm{E}$ $\left(90^{\circ}\right), 10^{\circ}, \mathrm{E}_{\mathrm{t}} 85 \%, \mathrm{E}_{2} 2 \%, \mathrm{E}_{1} 80 \%, \mathrm{E}_{0} 15 \%,-$, D. Dúbravková \& M. Zaliberová, 26/05, 3. 6. 2005.

4. SK, Slovenský kras Mts, Turňa nad Bodvou, Turniansky hradný vrch National Nature Reserve, karst rocky field above blue tourist path, a large homogenous stand, $48^{\circ} 36^{\prime} 36^{\prime \prime} \mathrm{N}, 20^{\circ} 52^{\prime} 22^{\prime \prime} \mathrm{E}, 25$ $\mathrm{m}^{2}, 340 \mathrm{~m}, \mathrm{SSW}\left(203^{\circ}\right), 40^{\circ}, \mathrm{E}_{\mathrm{t}} 60 \%,-, \mathrm{E}_{1} 60 \%, \mathrm{E}_{0} 10 \%, \mathrm{E}_{\mathrm{r}} 50 \%, \mathrm{D}$. Dúbravková \& M. Zaliberová, 12/05, 31. 5. 2005.

5. SK, Slovenský kras Mts, Turňa nad Bodvou, Turniansky hradný vrch National Nature Reserve, a slope over a farm, Bromus erectus takes over the stands with deeper soil (basis of a plateau), $48^{\circ} 36^{\prime} 37^{\prime \prime N}, 20^{\circ} 52^{\prime} 32^{\prime \prime E}, 25 \mathrm{~m}^{2}, 330 \mathrm{~m}$, SSW $\left(203^{\circ}\right), 10^{\circ}, \mathrm{E}_{\mathrm{t}} 85 \%$, -, $\mathrm{E}_{1} 80 \%, \mathrm{E}_{0} 5 \%$, -, D. Dúbravková \& M. Zaliberová, 14/05, 31. 5. 2005.

6. SK, Slovenský kras Mts, Vidová, Plešivská planina Plateau, Plešivská stráň, Nad Vidovou, 48³4'14"N, 20²6'19"E, 32 m², 555 $\mathrm{m}, \mathrm{E}\left(90^{\circ}\right), 15^{\circ}, \mathrm{E}_{\mathrm{t}} 90 \%, \mathrm{E}_{2} 1 \%, \mathrm{E}_{1} 90 \%, \mathrm{E}_{0} 15 \%, \mathrm{E}_{\mathrm{r}} 7 \%$, D. Dúbravková, J. Kolbek \& R. Šuvada, 4/06, 17. 5. 2006.

7. SK, Slovenský kras Mts, Plešivec, Plešivská planina Plateau, Plešivská stráň, Nad novým hámrom (Site of the European Importance), 48 $33^{\prime} 59^{\prime \prime} \mathrm{N}, 20^{\circ} 24^{\prime} 19^{\prime \prime} \mathrm{E}, 25 \mathrm{~m}^{2}, 476 \mathrm{~m}$, SWW $\left(250^{\circ}\right), 25^{\circ}$, $\mathrm{E}_{\mathrm{t}} 80 \%, \mathrm{E}_{2} 3 \%, \mathrm{E}_{1} 75 \%, \mathrm{E}_{0} 20 \%, \mathrm{E}_{\mathrm{r}} 10 \%$, D. Dúbravková, J. Kolbek \& R. Šuvada, 2/06, 17. 5. 2006.
8. HU, Aggteleki-karszt Mts, Jósvafö, Nagy-oldál, Bok, western part of the locality, behind a small valley Nagy-szod-vólgy, $48^{\circ} 30^{\prime} 22^{\prime \prime} \mathrm{N}, 20^{\circ} 33^{\prime} 43^{\prime \prime} \mathrm{E}, 25 \mathrm{~m}^{2}, 492 \mathrm{~m}$, SSW $\left(200^{\circ}\right), 25^{\circ}, \mathrm{E}_{\mathrm{t}} 95 \%$, $\mathrm{E}_{2} 1 \%, \mathrm{E}_{1} 95, \mathrm{E}_{0} 5 \%,-$, D. Dúbravková, 51/06, 1. 6. 2006.

9. SK, Slovenský kras Mts, Slavec, Plešivská planina Plateau, Slavecká stráň, an abandoned orchard, litter layer about $5 \mathrm{~cm}$ thick, $48^{\circ} 36^{\prime} 36^{\prime \prime} \mathrm{N}, 20^{\circ} 27^{\prime} 51^{\prime \prime E}, 24 \mathrm{~m}^{2}, 557 \mathrm{~m}$, SSE $\left(150^{\circ}\right), 45^{\circ}, \mathrm{E}_{\mathrm{t}}$ $85 \%,-, \mathrm{E}_{1} 80 \%, \mathrm{E}_{0} 10 \%, \mathrm{E}_{\mathrm{r}} 15 \%$, D. Dúbravková \& R. Šuvada, $6 / 06,18.5 .2006$

10. SK, Slovensky kras, Hrušov, $48^{\circ} 35^{\prime} 54^{\prime \prime N}$, 20³7'54"E, $32 \mathrm{~m}^{2}, 508$ $\mathrm{m}, \mathrm{S}\left(180^{\circ}\right), 30^{\circ}, \mathrm{E}_{\mathrm{t}} 60 \%, \mathrm{E}_{2} 4 \%, \mathrm{E}_{1} 60 \%, \mathrm{E}_{0} 3 \%, \mathrm{E}_{\mathrm{r}} 12 \%$, M. Janišová \& J. Kolbek, 4/06 MJ, 19. 5. 2006.

11. SK, Slovensky kras, Slavec, Plešivská planina Plateau, Slavecká stráň, the stand burnet few years ago, $48^{\circ} 35^{\prime} 32^{\prime \prime} \mathrm{N}, 20^{\circ} 27^{\prime} 54^{\prime \prime} \mathrm{E}$, $25 \mathrm{~m}^{2}, 484 \mathrm{~m}$, EES $\left(113^{\circ}\right), 33^{\circ}, \mathrm{E}_{\mathrm{t}} 80 \%,-, \mathrm{E}_{1} 75 \%, \mathrm{E}_{0} 3 \%, \mathrm{E}_{\mathrm{r}} 15 \%$, M. Janišová \& J. Kolbek, 1/06 MJ, 18. 5. 2006.

12. SK, Slovenský kras Mts, Plešivec, Plešivská planina Plateau, Plešivská strán, Nad novým hámrom, slope above a small factory in Plešivec, 48 33' $53^{\prime \prime} \mathrm{N}, 20^{\circ} 24^{\prime} 21^{\prime \prime} \mathrm{E}, 25 \mathrm{~m}^{2}, 468 \mathrm{~m}, \mathrm{~W}\left(265^{\circ}\right), 25^{\circ}$, -, E $\mathrm{E}_{2} 3 \%, \mathrm{E}_{1} 70 \%, \mathrm{E}_{0} 15 \%, \mathrm{E}_{\mathrm{r}} 15 \%$, D. Dúbravková, J. Kolbek \& R. Šuvada, 3/06, 17. 5. 2006

13. HU, Aggteleki-karszt Mts, Jósvafö, Nagy-oldál, 48³0'11"N, $20^{\circ} 33^{\prime} 58^{\prime \prime E}, 25 \mathrm{~m}^{2}, 430 \mathrm{~m}$, SSW $\left(195^{\circ}\right), 30^{\circ}, \mathrm{E}_{\mathrm{t}} 75 \%,-, \mathrm{E}_{1} 70 \%, \mathrm{E}_{0}$ $10 \%, \mathrm{E}_{\mathrm{r}} 30 \%$, D. Dúbravková, 50/06, 1. 6. 2006.

14. SK, Slovenský kras Mts, Hrušovo, Silická planina Plateau, Hrušovská lesostep National Nature Reserve, thin soil layer, $48^{\circ} 35^{\prime} 55^{\prime \prime} \mathrm{N}, 20^{\circ} 37^{\prime} 48^{\prime \prime} \mathrm{E}, 8 \mathrm{~m}^{2}, 500 \mathrm{~m}$, SSW $\left(210^{\circ}\right), 30^{\circ}, \mathrm{E}_{\mathrm{t}} 55 \%$, -, $\mathrm{E}_{1} 50 \%, \mathrm{E}_{0} 30 \%,-$, D. Dúbravková \& R. Šuvada, 8/06, 19. 5. 2006.

15. HU, Aggteleki-karszt Mts, Bódvarákó, Szalonnai-hegység, Esztramos-hegy Mt., near the hilltop, $48^{\circ} 31^{\prime} 01^{\prime \prime} \mathrm{N}, 20^{\circ} 44^{\prime} 51^{\prime \prime E}$, $25 \mathrm{~m}^{2}, 336 \mathrm{~m}, \mathrm{SSW}\left(203^{\circ}\right), 25^{\circ}, \mathrm{E}_{\mathrm{t}} 75 \%,-, \mathrm{E}_{1} 60 \%, \mathrm{E}_{0} 18 \%, \mathrm{E}_{\mathrm{r}}$ $30 \%$, D. Dúbravková, E. Illyés \& V. Virók, 34/06, 29. 5. 2006.

16. SK, Slovensky kras, Hrušov, 48³5'54"N, 20³7'53"E, 6 m², 519 
$\mathrm{m}, \operatorname{SSW}\left(200^{\circ}\right), 30^{\circ}, \mathrm{E}_{\mathrm{t}} 45 \%,-, \mathrm{E}_{1} 30 \%, \mathrm{E}_{0} 10 \%, \mathrm{E}_{\mathrm{r}} 40 \%$, M. Janišová \& J. Kolbek, 3/06 MJ, 19. 5. 2006.

17. SK, Slovenský kras Mts, Silica, Silická planina Plateau, $48^{\circ} 34^{\prime} 03^{\prime \prime} \mathrm{N}, 20^{\circ} 28^{\prime} 28^{\prime \prime} \mathrm{E}, 25 \mathrm{~m}^{2}, 530 \mathrm{~m}$, SW $\left(235^{\circ}\right), 20^{\circ}$, E $\mathrm{t} 80 \%,-$, $\mathrm{E}_{1} 75 \%, \mathrm{E}_{0} 20 \%, \mathrm{E}_{\mathrm{r}} 20 \%$, D. Dúbravková, M. Janišová, J. Kolbek \& R. Šuvada, 5/06, 18. 5. 2006.

18. SK, Slovenský kras Mts, Plešivec, Plešivská planina Plateau, above blue tourist path, $48^{\circ} 33^{\prime} 55^{\prime \prime} \mathrm{N}, 20^{\circ} 24^{\prime} 09^{\prime \prime} \mathrm{E}, 21 \mathrm{~m}^{2}, 344 \mathrm{~m}, \mathrm{~W}$ $\left(270^{\circ}\right), 35^{\circ}, \mathrm{E}_{\mathrm{t}} 75 \%, \mathrm{E}_{2} 5 \%, \mathrm{E}_{1} 75 \%, \mathrm{E}_{0} 10 \%, \mathrm{E}_{\mathrm{r}} 15 \%$, D. Dúbravková \& M. Zaliberová, 20/05, 2.6. 2005.

19. SK, Slovensky kras, Silica, $48^{\circ} 34^{\prime} 03^{\prime \prime} \mathrm{N}, 20^{\circ} 28^{\prime} 28^{\prime \prime} \mathrm{E}, 25 \mathrm{~m}^{2}, 540 \mathrm{~m}$, SWW $\left(237^{\circ}\right), 25^{\circ}, \mathrm{E}_{\mathrm{t}} 75 \%,-, \mathrm{E}_{1} 70 \%, \mathrm{E}_{0} 5 \%, \mathrm{E}_{\mathrm{r}} 10 \%$, M. Janišová \& J. Kolbek, 2/06 MJ, 18. 5. 2006.

20. SK, Slovenský kras Mts, Hrušovo, Silická planina Plateau, Hrušovská lesostep National Nature Reserve, a small rocky ridge, $48^{\circ} 35^{\prime} 54^{\prime \prime} \mathrm{N}, 20^{\circ} 37^{\prime} 55^{\prime \prime} \mathrm{E}, 4.5 \mathrm{~m}^{2}, 525 \mathrm{~m}, \mathrm{SSW}\left(210^{\circ}\right), 45^{\circ}, \mathrm{E}_{\mathrm{t}} 50 \%$, -, $\mathrm{E}_{1} 45 \%, \mathrm{E}_{0} 25 \%, \mathrm{E}_{\mathrm{r}} 40 \%$, D. Dúbravková \& R. Šuvada, 7/06, 19. 5. 2006.

21. SK, Slovenský kras Mts, Vidová, Plešivská planina Plateau, above a forest road connecting village and plateau, $48^{\circ} 34^{\prime} 14 " \mathrm{~N}$, $20^{\circ} 26^{\prime} 36^{\prime \prime} \mathrm{E}, 25 \mathrm{~m}^{2}, 418 \mathrm{~m}, \mathrm{SE}\left(135^{\circ}\right), 5^{\circ}, \mathrm{E}_{\mathrm{t}} 70 \%,-, \mathrm{E}_{1} 60 \%, \mathrm{E}_{0}$ $10 \%, \mathrm{E}_{\mathrm{r}} 40 \%$, D. Dúbravková \& M. Zaliberová, 21/05, 2. 6. 2005.

22. SK, Slovenský kras Mts, Vidová, Plešivská planina Plateau, near a forest road connecting village and plateau, under an edge of plateau, $48^{\circ} 34^{\prime} 19^{\prime \prime} \mathrm{N}, 20^{\circ} 26^{\prime} 29^{\prime \prime} \mathrm{E}, 25 \mathrm{~m}^{2}, 470 \mathrm{~m}$, SW $\left(225^{\circ}\right), 10^{\circ}$, $\mathrm{E}_{\mathrm{t}} 70 \%,-, \mathrm{E}_{1} 55 \%, \mathrm{E}_{0} 20 \%,-, \mathrm{D}$. Dúbravková \& M. Zaliberová, $23 / 05,2.6 .2005$.

23. HU, Aggteleki-karszt Mts, obec Jósvafö, Jósva-völgy, a grassland above the road curve, $1 \mathrm{~km}$ eastwards from the village, $48^{\circ} 28^{\prime} 44^{\prime \prime} \mathrm{N}, 20^{\circ} 34^{\prime} 29^{\prime \prime} \mathrm{E}, 25 \mathrm{~m}^{2}, 238 \mathrm{~m}, \mathrm{~S}\left(178^{\circ}\right), 25^{\circ}, \mathrm{E}_{\mathrm{t}} 80 \%,-, \mathrm{E}_{1}$ $75 \%, \mathrm{E}_{0} 10 \%, \mathrm{E}_{\mathrm{r}} 10 \%$, D. Dúbravková, E. Illyés \& V. Virók, 37/06, 29. 5. 2006.

24. HU, Aggteleki-karszt Mts, Jósvafö, Nagy-oldál, 48³0'10"N, $20^{\circ} 34^{\prime} 07^{\prime \prime} \mathrm{E}, 25 \mathrm{~m}^{2}, 409 \mathrm{~m}, \mathrm{~S}\left(170^{\circ}\right), 40^{\circ}, \mathrm{E}_{\mathrm{t}} 65 \%,-, \mathrm{E}_{1} 60 \%, \mathrm{E}_{0} 5 \%$, -, D. Dúbravková, 49/06, 1. 6. 2006.

25. HU, Aggteleki-karszt Mts, Alsó-hegy Mt., Komjáti, a karst rocky field above the villge, $48^{\circ} 33^{\prime} 21^{\prime \prime} \mathrm{N}, 20^{\circ} 44^{\prime} 57^{\prime \prime} \mathrm{E}, 25 \mathrm{~m}^{2}, 281 \mathrm{~m}$, SSE $\left(158^{\circ}\right), 25^{\circ}, \mathrm{E}_{\mathrm{t}} 90 \%, \mathrm{E}_{2} 10 \%, \mathrm{E}_{1} 80 \%, \mathrm{E}_{0} 15 \%$, -, D. Dúbravková, 46/06, 31. 5. 2006.

26. HU, Aggteleki-karszt Mts, Alsó-hegy Mt., Szögliget, Szád-vár, an oppening on S slope of the castle hill, 48 $32^{\circ} 31^{\prime \prime} \mathrm{N}, 20^{\circ} 39^{\prime} 49^{\prime \prime} \mathrm{E}, 24$ $\mathrm{m}^{2}, 347 \mathrm{~m}, \mathrm{SSE}\left(165^{\circ}\right), 35^{\circ}, \mathrm{E}_{\mathrm{t}} 65 \%,-, \mathrm{E}_{1} 60 \%, \mathrm{E}_{0} 20 \%, \mathrm{E}_{\mathrm{r}} 40 \%, \mathrm{D}$. Dúbravková, E. Illyés \& V. Virók, 43/06, 30. 5. 2006.

27. HU, Aggteleki-karszt Mts, Alsó-hegy Mt., Komjáti, NW from the village, a karst rocky field above a farm, $48^{\circ} 33^{\prime} 19^{\prime \prime} \mathrm{N}, 20^{\circ} 44^{\prime} 53^{\prime \prime} \mathrm{E}$, $9 \mathrm{~m}^{2}, 260 \mathrm{~m}, \operatorname{SSE}\left(160^{\circ}\right), 15^{\circ}, \mathrm{E}_{\mathrm{t}} 50 \%,-, \mathrm{E}_{1} 40 \%, \mathrm{E}_{0} 10 \%, \mathrm{E}_{\mathrm{r}} 50 \%$, D. Dúbravková, 45/06, 31. 5. 2006.

28. HU, Aggteleki-karszt Mts, Alsó-hegy Mt., Komjáti, a karst rocky field above the centre of the village, $48^{\circ} 33^{\prime} 20^{\prime \prime} \mathrm{N}, 20^{\circ} 45^{\prime} 06^{\prime \prime} \mathrm{E}, 12$ $\mathrm{m}^{2}, 244 \mathrm{~m}, \operatorname{SSE}\left(150^{\circ}\right), 12^{\circ}, \mathrm{E}_{\mathrm{t}} 70 \%,-, \mathrm{E}_{1} 60 \%, \mathrm{E}_{0} 20 \%,-, \mathrm{D}$. Dúbravková, 47/06, 31. 5. 2006.

29. HU, Aggteleki-karszt Mts, Alsó-hegy, Komjáti, a karst rocky field above the village, $48^{\circ} 33^{\prime} 20^{\prime \prime} \mathrm{N}, 20^{\circ} 45^{\prime} 10^{\prime \prime} \mathrm{E}, 25 \mathrm{~m}^{2}, 231 \mathrm{~m}$, $\operatorname{SSE}\left(160^{\circ}\right), 25^{\circ}, \mathrm{E}_{\mathrm{t}} 65 \%,-, \mathrm{E}_{1} 60 \%, \mathrm{E}_{0} 20 \%, \mathrm{E}_{\mathrm{r}} 40 \%$, D. Dúbravková, 48/06, 31. 5. 2006.

30. HU, Aggteleki-karszt Mts, Alsó-hegy, Komjáti, about $100 \mathrm{~m}$ above the vineyards NW from the village, $48^{\circ} 33^{\prime} 15^{\prime \prime} \mathrm{N}, 20^{\circ} 44^{\prime} 48^{\prime \prime} \mathrm{E}$, $25 \mathrm{~m}^{2}, 248 \mathrm{~m}, \mathrm{~S}\left(170^{\circ}\right), 15^{\circ}, \mathrm{E}_{\mathrm{t}} 90 \%,-, \mathrm{E}_{1} 85 \%, \mathrm{E}_{0} 30 \%, \mathrm{E}_{\mathrm{r}} 10 \%, \mathrm{D}$. Dúbravková, 44/06, 31. 5. 2006.

31. SK, Slovenský kras Mts, Kečov, Kečovské škrapy National Nature Reserve, Arhenatherum elatius takes over the stand, $48^{\circ} 29^{\prime} 40^{\prime \prime} \mathrm{N}$, $20^{\circ} 29^{\prime} 16^{\prime} \mathrm{E}, 25 \mathrm{~m}^{2}, 420 \mathrm{~m}, \mathrm{SW}\left(225^{\circ}\right), 10^{\circ}, \mathrm{E}_{\mathrm{t}} 90 \%,-, \mathrm{E}_{1} 85 \%, \mathrm{E}_{0}$ $10 \%,-$, D. Dúbravková \& M. Zaliberová, 18/05, 1. 6. 2005.

32. HU, Aggteleki-karszt Mts, Jósvafö, Kossuth-barlang Mt., W slope, $48^{\circ} 29^{\prime} 05^{\prime \prime} \mathrm{N}, 20^{\circ} 33^{\prime} 08^{\prime \prime} \mathrm{E}, 25 \mathrm{~m}^{2}, 258 \mathrm{~m}$, NWW $\left(290^{\circ}\right), 45^{\circ}, \mathrm{E}_{\mathrm{t}}$
$100 \%, \mathrm{E}_{2} 1 \%, \mathrm{E}_{1} 100 \%, \mathrm{E}_{0} 60 \%,-$, D. Dúbravková, E. Illyés \& V. Virók, 41/06, 30. 5. 2006

33. HU, Aggteleki-karszt Mts, Aggtelek, Galya-tetö, a karst rocky field above the village, $48^{\circ} 28^{\prime} 13^{\prime \prime} \mathrm{N}, 20^{\circ} 30^{\prime} 49^{\prime \prime} \mathrm{E}, 25 \mathrm{~m}^{2}$, $399 \mathrm{~m}$, W $\left(260^{\circ}\right), 20^{\circ}, \mathrm{E}_{\mathrm{t}} 90 \%,-, \mathrm{E}_{1} 85 \%, \mathrm{E}_{0} 15 \%,-, \mathrm{D}$. Dúbravková, E. Illyés \& V. Virók, 38/06, 29. 5. 2006.

34. SK, Slovenský kras Mts, Kečov, Kečovské škrapy National Na-

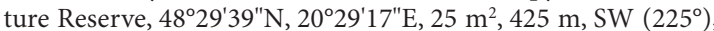
$15^{\circ}, \mathrm{E}_{\mathrm{t}} 80 \%,-, \mathrm{E}_{1} 75 \%, \mathrm{E}_{0} 10 \%,-, \mathrm{D}$. Dúbravková \& M. Zaliberová, $17 / 05,1.6 .2005$.

35. SK, Slovenský kras Mts, Jablonov nad Turňou, Horný vrch Plateau, Hodovník Mt.(eastwards from Kukudičova skala Mt.), $48^{\circ} 36^{\prime} 16^{\prime \prime} \mathrm{N}, 20^{\circ} 40^{\prime} 05^{\prime \prime} \mathrm{E}, 24 \mathrm{~m}^{2}, 560 \mathrm{~m}$, SSW $\left(210^{\circ}\right), 15^{\circ}, \mathrm{E}_{\mathrm{t}} 85 \%$, $\mathrm{E}_{2} 5 \%, \mathrm{E}_{1} 65 \%, \mathrm{E}_{0} 40 \%, \mathrm{E}_{\mathrm{r}} 15 \%$, D. Dúbravková \& M. Dúbravka, $1 / 07,30.4 .2007$

36. SK, Slovenský kras Mts, Turňa nad Bodvou, Turniansky hradný vrch National Nature Reserve, near the castle, $48^{\circ} 36^{\prime} 37^{\prime \prime} \mathrm{N}$, $20^{\circ} 52^{\prime} 26^{\prime \prime E}, 15 \mathrm{~m}^{2}, 345 \mathrm{~m}, \mathrm{~S}\left(180^{\circ}\right), 25^{\circ}, \mathrm{E}_{\mathrm{t}} 80 \%,-, \mathrm{E}_{1} 70 \%, \mathrm{E}_{0}$ 15\%, -, D. Dúbravková \& M. Zaliberová, 13/05, 31. 5. 2005.

37. HU, Aggteleki-karszt Mts, Bódvarákó, Szalonnai-hegység, Esztramos-hegy Mt., edge of a quarry, $48^{\circ} 30^{\prime} 59^{\prime \prime} \mathrm{N}, 20^{\circ} 44^{\prime} 50^{\prime \prime} \mathrm{E}$, $25 \mathrm{~m}^{2}, 320 \mathrm{~m}, \mathrm{SSW}\left(195^{\circ}\right), 20^{\circ}, \mathrm{E}_{\mathrm{t}} 85 \%, \mathrm{E}_{2} 1 \%, \mathrm{E}_{1} 80 \%, \mathrm{E}_{0} 10 \%$, -, D. Dúbravková, E. Illyés \& V. Virók, 35/06, 19. 5. 2006.

38. HU, Aggteleki-karszt Mts, Jósvafö, Kosuth-barlang, above the $\mathrm{N}$ part of village, a rocky field on right side of red tourist path, $48^{\circ} 29^{\prime} 08^{\prime \prime} \mathrm{N}, 20^{\circ} 33^{\prime} 09^{\prime \prime} \mathrm{E}, 24 \mathrm{~m}^{2}, 261 \mathrm{~m}$, SWW $\left(245^{\circ}\right), 45^{\circ}, \mathrm{E}_{\mathrm{t}} 60 \%$, $\mathrm{E}_{2} 5 \%, \mathrm{E}_{1} 55 \%, \mathrm{E}_{0} 40 \%,-$, D. Dúbravková, E. Illyés \& V. Virók, $42 / 06,30.5 .2006$.

39. HU, Aggteleki-karszt Mts, Jósvafö, N from the village, a pasture located between blue and red tourist path, $48^{\circ} 29^{\prime} 31^{\prime \prime} \mathrm{N}$, $20^{\circ} 33^{\prime} 19 " \mathrm{E}, 25 \mathrm{~m}^{2}, 281 \mathrm{~m},-,-, \mathrm{E}_{\mathrm{t}}$ 98\%, -, E $185 \%, \mathrm{E}_{0} 40 \%,-$, D. Dúbravková, 52/06, 1.6. 2006.

40. HU, Aggteleki-karszt Mts, Aggtelek, Szölö-hegy (elevation point $440 \mathrm{~m}$ ), E of the village, near the quarry Aggtelek Köbánya, an $10-15$ years abandoned pasture for catle, $48^{\circ} 28^{\prime} 05^{\prime \prime} \mathrm{N}$, $20^{\circ} 31^{\prime} 13^{\prime \prime E}, 25 \mathrm{~m}^{2}, 420 \mathrm{~m}$, SSW (205), 5 , E $98 \%$, -, E $98 \%$, $\mathrm{E}_{0} 40 \%,-$, D. Dúbravková, E. Illyés \& V. Virók, 40/06, 30. 5. 2006.

41. SK, Slovenský kras Mts, Vidová, Plešivská planina Plateau, above a forest road leading to top of the plateau, under the edge of the plateau, $48^{\circ} 34^{\prime} 20^{\prime \prime} \mathrm{N}, 20^{\circ} 26^{\prime} 30^{\prime \prime} \mathrm{E}, 25 \mathrm{~m}^{2}, 490 \mathrm{~m}$, SW $\left(225^{\circ}\right)$, $2^{\circ}, \mathrm{E}_{\mathrm{t}} 90 \%, \mathrm{E}_{2} 5 \%, \mathrm{E}_{1} 85 \%, \mathrm{E}_{0} 10 \%, \mathrm{E}_{\mathrm{r}} 20 \%$, D. Dúbravková \& M Zaliberová, 22/05, 2. 6. 2005.

42. SK, Slovenský kras Mts, Domica, Domické škrapy National Nature Reserve, above a tourist path leading to Starňa, W of the Domica cave entrance, $48^{\circ} 28^{\prime} 43^{\prime \prime} \mathrm{N}, 20^{\circ} 28^{\prime} 04^{\prime \prime} \mathrm{E}, 21 \mathrm{~m}^{2}, 380 \mathrm{~m}$ $\mathrm{S}\left(180^{\circ}\right), 25^{\circ}, \mathrm{E}_{\mathrm{t}} 90 \%,-, \mathrm{E}_{1} 90 \%, \mathrm{E}_{0} 5 \%,-, \mathrm{D}$. Dúbravková \& M. Zaliberová, 16/05, 1. 6. 2005.

43. SK, Slovenský kras Mts, Slavec, Plešivská planina Plateau, slope over the E part of village, $48^{\circ} 35^{\prime} 26^{\prime \prime} \mathrm{N}, 20^{\circ} 28^{\prime} 00^{\prime \prime} \mathrm{E}, 25 \mathrm{~m}^{2}, 335 \mathrm{~m}$, $\mathrm{W}\left(270^{\circ}\right), 50^{\circ}, \mathrm{E}_{\mathrm{t}} 80 \%,-, \mathrm{E}_{1} 75 \%, \mathrm{E}_{0} 15 \%,-$, D. Dúbravková \& $\mathrm{M}$. Zaliberová, 24/05, 2. 6. 2005.

44. SK, Slovenský kras Mts, Domica, Domické škrapy National Nature Reserve, above red tourist path, $\mathrm{E}$ of the Domica cave entrance, $48^{\circ} 28^{\prime} 42^{\prime \prime} \mathrm{N}, 20^{\circ} 28^{\prime} 20^{\prime \prime} \mathrm{E}, 17 \mathrm{~m}^{2}, 380 \mathrm{~m}, \mathrm{~S}\left(180^{\circ}\right), 5^{\circ}, \mathrm{E}_{\mathrm{t}}$ $90 \%,-, \mathrm{E}_{1} 90 \%, \mathrm{E}_{0} 3 \%, \mathrm{E}_{\mathrm{r}} 7 \%$, D. Dúbravková \& M. Zaliberová, $15 / 05,1.6 .2005$.

45. SK, Slovenský kras Mts, Silica, Silická planina Plateau, Fabiánka Hill, an orchard that burnet about $2-3$ years ago, $48^{\circ} 33^{\prime} 52^{\prime \prime} \mathrm{N}$, $20^{\circ} 32^{\prime} 38^{\prime \prime} \mathrm{E}, 25 \mathrm{~m}^{2}, 600 \mathrm{~m}, \mathrm{~S}\left(180^{\circ}\right), 10^{\circ}, \mathrm{E}_{\mathrm{t}} 70 \%,-, \mathrm{E}_{1} 70 \%,-,-$, D. Dúbravková \& M. Zaliberová, 19/05, 1. 6. 2005.

46. HU, Aggteleki-karszt Mts, Szölösardö, Galyaság, Zabaryikhegy Mt., Brachypodium pinnatum dominates the neighbouring stands, $48^{\circ} 27^{\prime} 28^{\prime \prime} \mathrm{N}, 20^{\circ} 37^{\prime} 40^{\prime \prime} \mathrm{E}, 25 \mathrm{~m}^{2}, 405 \mathrm{~m}, \mathrm{~S}\left(175^{\circ}\right), 10^{\circ}$, E $100 \%, \mathrm{E}_{2} 1 \%, \mathrm{E}_{1} 100 \%, \mathrm{E}_{0} 5 \%,-$, D. Dúbravková, E. Illyés \& V. Virók, 36/06, 29. 5. 2006. 